\title{
Bibliography of Finnish Population Studies 2004-2006
}

\author{
ULLA-MAIJA MATTILA, M.A. Information Specialist \\ The Population Research Institute \\ Väestöliitto, the Family Federation of Finland \\ Helsinki, Finland
}

The bibliography covers the literature on population research published by Finnish authors in Finland and abroad mainly during 2004-2006. Also included are studies by foreign authors on Finnish population. Included are independent publications and articles in periodicals and compiled works as well as nationwide Finnish statistics. In general the bibliography excludes nonscientific articles in newspapers and weeklies as well as unpublished reports and academic theses. Also not included are studies presented in proceedings of conferences held in Finland if they are written abroad and treated subjects outside Finland. Neither are comparative studies where Finland not forms a substantial part included in the bibliography. Coverage is less complete in peripheral fields.

In principle the main divisions appearing in the Population Index have been used with added subdivisions better suiting Finnish circumstances. Studies covering several fields of demography, which should rightly be listed in two or more divisions, are included in only one division, i.e. in the division representing the primary field, on which the report is centered.

Lists of literature on population research have been published in Yearbooks II-IV of the Family Federation of Finland, since 1960 in the Yearbook of Population Research in Finland, and from 2006 onwards in the Finnish Yearbook of Population Research.

\section{A. GENERAL POPULATION STUDIES AND THEORIES}

(No citations)

\section{B. REGIONAL POPULATION STUDIES}

Etelä-Suomen maakuntien liittouma [The South Finland Regional Alliance]. 2004. Etelä-Suomen aluerakenne 2030: väestö ja työpaikat [Regional structure of Southern Finland 2030: population and jobs]. Helsinki: Etelä-Suomen maakuntien liittouma. 32, [2] pp. ISBN 951-98634-4-3. Accessed on Feb. 18, 2008. Available online at http://liitto.ita-uusimaa.fi/files/Tiedostot/aluerakenne2 2030.pdf 
Keränen, Heikki. 2004. Maaseudun aluerakenteen muutos 1990-2002 [Regional change of the rural areas in 1990-2002]. Working papers, REDEC Kajaani, No. 48. Kajaani: Oulun yliopisto. 128 pp. ISBN 951-42-7408-3.

Nivalainen, Satu and Raija Volk. 2004. Alueellinen väestökehitys vuoteen 2030 ja siihen vaikuttavat tekijät [Regional population development until 2030 and the factors affecting it]. Pp. 13-78 in Alueellinen väestökehitys ja politiikan uudistamistarpeet: tulevaisuusselonteon liiteraportti 2, edited by Mikko Kautto. Valtioneuvoston kanslian julkaisarja, No. 30/2004. Helsinki: Valtioneuvoston kanslia. Accessed on March 3, 2008. Available online http://www.vnk.fi/julkaisukansio/2004/j30-alueellinen-vaestokehitys/pdf/134312.pdf

Pirkanmaan liitto [The Council of Tampere Region]. 2006. Pirkanmaan väestönmuutokset 2005 ja työssäkäyntiliikenne 2003 [Population changes in Pirkanmaa in 2005 and commuting traffic in 2003]. Sarja B, No. 98. Tampere: Pirkanmaan liitto. 30 pp. Accessed on Jan. 31, 2008. Available online at http://www.pirkanmaa.fi/suomi/pdf/ Vaestonmuutokset\%202005.pdf

\section{SPATIAL DISTRIBUTIONS}

Kangasharju, Aki. 2004. Alueellinen keskittyminen historiaa ja tulevaisuutta - myös Suomessa [Regional concentration is history and future - also in Finland]. Kuntapuntari (3):3-6.

Saari, Matti and Pasi Nevalainen. 2006. Väestön keskittyminen hidastunut [The concentration of population has slowed down]. Kuntapuntari (3):12-6.

\section{TRENDS IN POPULATION GROWTH AND SIZE}

Coleman, David. 2004. Väestön vähenemisen ankara haaste [The severe challenge of population decline]. Ulkopolitiikka(1):31-32, 44-45.

Honkanen, Ossi and Markus Rapo. 2005. Suomen väkiluvun kehitys 1995-2004, väestönmuutokset ja väestöennusteet [The development of Finland's population in 1995-2004, population changes, and population projections]. Pp. 171-4 in Kymmenvuotiskatsaus 2005: teemana yritystoiminta. Helsinki: Tilastokeskus.

Kautto, Mikko and Marja-Liisa Parjanne. 2004. Väestön ikärakenteen muutos ja siihen varautuminen: tulevaisuusseloteon liiteraportti 1 [The change in the age structure of the population and being prepared for it: Appendix 1 of the Government report on future]. Valtioneuvoston julkaisusarja, No. 29/2004. Helsinki: Valtioneuvoston kanslia. 147 pp. ISBN 952-5354-71-7. Accessed on March 3, 2008. Available online at http:// www.vnk.fi/julkaisukansio/2004/j29-vaeston-ikarakenteen-muutos/pdf/fi.pdf

Laakso, Seppo and Pekka Vuori. 2004. Population projection for Helsinki. Kvartti (3):7-10.

Murphy, Michael, Pekka Martikainen, and Sophie Pennec. 2006. Demographic change and the supply of potential family supporters in Britain, Finland and France in the period 1911-2050. European Journal of Population 22(3):219-40. 
Nieminen, Mauri. 2005. Ikärakenteen muutos [Change in age structure]. Pp. 35-50 in Tallella ikä eletty...:ikääntyminen tilastoissa [Aging in statistics]. Elinolot, 2005. Helsinki: Statistics Finland.

Nieminen, Mauri and Seppo Koskinen. 2005. Väestö [Population]. Pp. 41-49 in Suomalaisten terveys, edited by Arpo Aromaa, Jussi Huttunen, Seppo Koskinen, and Juha Teperi. Helsinki: Duodecim \& KTL \& STAKES.

Sinisalo, Timo. 2006. Väestön ikääntymisen haasteet kunnille [The challenges of population aging to municipalities]. Pp. 38-48 in Muuttaako Onni maalle? Suurten ikäluokkien valinta: Muuttoliikesymposium 2005, Turku 23.-24.11, edited by Elli Heikkilä. Siirtolaisuustutkimuksia, No. A 28. Turku: Siirtolaisuusinstituutti.

Söderling, Ismo. 2005. Suomalainen väestökysymys eurooppalaisessa kehyksessä [The Finnish population issue in the European framework]. Tiedepolitiikka 30(4):25-31.

Uusitalo, Hannu. 2004. Miten reagoida väestöennusteiden epävarmuuteen? [How to react to the uncertainty of population projections]. Työeläke(1):26-28.

Valkonen, Tapani. 2004. Elinajanodotteen kehitys, väestön vanheneminen ja tulevaisuuden terveysongelmat maailmassa ja meillä [The development of life expectancy, aging of population, and the future health problems in Finland and elsewhere]. Duodecim 120(18):2173-9.

Vuori, Pekka. 2004. Helsingin väestönkehitys 2000-luvulla = Befolkningsutvecklingen i Helsingfors på 2000-talet [The population development of Helsinki in the 2000s]. Kvartti(1):6-11

\section{E. MORTALITY}

Ahonen, Hilkka. 2005. Kuolleisuus [Mortality]. Pp. 131-42 in Tallella ikä eletty...: ikääntyminen tilastoissa. Elinolot, 2005. Helsinki: Statistics Finland.

Alho, Juha and Niku Määttänen. 2006. Aggregate mortality risk and the insurance value of annuities. Keskusteluaiheita, No. 1005. Helsinki: Elinkeinoelämän tutkimuslaitos. 15, [4] pp.

Avendaño, M., A.E. Kunst, M. Huisman, F. van Lenthe, M. Bopp, C. Borrell, T. Valkonen, E. Regidor, G. Costa, A. Donkin, J.K. Borgan, P. Deboosere, S. Gadeyne, T. Spadea, O. Andersen, and J.P. Mackenbach. 2004. Educational level and stroke mortality: a comparison of 10 European populations during the 1990s. Stroke 35(2):432-37.

Avendaño, M., A. E. Kunst, F. van Lenthe, V. Bos, G. Costa, T.Valkonen, M. Cardano, S. Harding, J.-K. Borgan, M. Glickman, A. Reid, and J. P. Mackenbach. 2005. Trends in socioeconomic disparities in stroke mortality in six European countries between 1981-1985 and 1991-1995. American Journal of Epidemiology 161(1):52-61.

Barego, Noël. 2006. Physical activity, cardiovascular risk factors and mortality. Kuopion yliopiston julkaisuja. D, Lääketiede, No. 377. Kuopio: University of Kuopio. 107, [41] pp. ISBN 951-27-0397-1. Accessed on Dec.10, 2007. Available online at http://www.uku.fi/vaitokset/2006/isbn951-27-0397-1.pdf 
Blomgren, Jenni, Pekka Martikainen, Pia Mäkelä, and Tapani Valkonen. 2004. The effects of regional characteristics on alcohol-related mortality - a register-based multilevel analysis of 1.1 million men. Social Science \& Medicine 58(12):2523-35.

Borrell, C., A. Plasència, M. Huisman, G. Costa, A. Kunst, O. Andersen, M. Bopp, J.-K. Borgan, P. Deboosere, M. Glickman, S. Gadeyne, C. Minder, E. Regidor, T. Spadea, T. Valkonen, and J.P. Mackenbach. 2005. Education level inequalities and transportation injury mortality in the middle aged and elderly in European settings. Injury Prevention 11:138-42.

Deneux-Tharaux, Catherine, Cynthia Berg, Marie-Hélène Bouvier-Colle, Mika Gissler, Margaret Harper, Angela Nannini, Sophie Alexander, Katherine Wildman, Gerard Breart, and Pierre Buekens. 2005. Underreporting of pregnancy-related mortality in the United States and Europe. Obstetrics \& Gynecology 106(4):684-92.

Elo, Irma T., Pekka Martikainen, and Kirsten P. Smith. 2006. Socioeconomic differentials in mortality in Finland and the United States: the role of education and income. European Journal of Population 22(2):179-203.

Elovainio, M., P. Leino-Arjas, J. Vahtera, and M. Kivimäki. 2006. Justice at work and cardiovascular mortality: a prospective cohort study. Journal of Psychosomatic Research 61(2):271-4.

Gissler, Mika, Cynthia Berg, Marie-Hélène Bouvier-Colle, and Pierre Buekens. 2005. Injury deaths, suicides and homicides associated with pregnancy, Finland 1987-2000. The European Journal of Public Health 15(5):459-63.

Gissler, Mika, Cynthia Berg, Marie-Hélène Bouvier-Colle, and Pierre Buekens. 2004. Pregnancy-associated mortality after birth, spontaneous abortion, or induced abortion in Finland, 1987-2000. American of Obstetrics and Gynecology 190(2):422-7.

Gissler, Mika. 2005. Raskauteen liittyvät kuolemat [Pregnancy-associated and pregnancy-related deaths]. Suomen Lääkärilehti 60(7):783-86.

Hinkula, Marianne, Antti Kauppila, Simo Näyhä, and Eero Pukkala. 2006. Causespecific mortality of grand multiparous women in Finland. American Journal of Epidemiology 163(4):367-73.

Huisman, M., A.E. Kunst, O. Andersen, M. Bopp, J.K. Borgan, C. Borrell, G. Costa, P. Deboosere, G. Desplanques, A. Donkin, S. Gadeyne, C. Minder, E. Regidor, T. Spadea, and T. Valkonen. 2004. Socioeconomic inequalities in mortality among elderly people in 11 European populations. Journal of Epidemiology and Community Health 58(6):468-75.

Huisman, Martijn, Anton E. Kunst, Mathias Bopp, Jens-Kristian Borgan, Carme Borrell, Giuseppe Costa, Patrick Deboosere, Sylvie Gadeyne, Myer Glickman, Chiara Marinacci, Christoph Minder, Enrique Regidor, Tapani Valkonen, and Johan P. Mackenbach. 2005. Educational inequalities in cause-specific mortality in middle-aged and older men and women in eight western European populations. Lancet 365(9458):493-500.

Johansson, Edvard, Petri Böckerman, Ritva Prättälä, and Antti Uutela. 2005. Alcohol 
mortality, drinking behaviour, and business cycles: are slumps really dry seasons? Discussion papers, No. 986. Helsinki: ETLA The Research Institute of the Finnish Economy. 10, [3] pp. Accessed on Dec. 27, 2007. Available online at http://www.etla.fi/files/1342_Dp986.pdf

Jousilahti, Pekka, Veikko Salomaa, Kari Kuulasmaa, Matti Niemelä, and Erkki Vartiainen. 2005. Total and cause specific mortality among participants and nonparticipants of population based health surveys: a comprehensive follow up of 54372 Finnish men and women. Journal of Epidemiology and Community Health 59(4):310-5.

Kallunki, Marjo, Marjo Renko, and Matti Uhari. 2004. Pikkulasten kuolleisuus Suomessa vuosina 1969-96 [Mortality of small children in Finland in 1969-96]. Duodecim 120(17):2100-7.

Kauhanen, Laura, Hanna-Maaria Lakka, John W. Lynch, and Jussi Kauhanen. 2006. Social disadvantages in childhood and risk of all-cause death and cardiovascular disease in later life: a comparison of historical and retrospective childhood information. International Journal of Epidemiology 35(4):962-8.

Kumpula, Heli, Anne Lounamaa, Meri Paavola, Philippe Lunetta, and Antti Impinen (ed.). 2006. Nuorten miesten tapaturmat ja väkivalta [Injuries and violence among young men]. Sosiaali- ja terveysministeriön selvityksiä, No. 71, 2006. Helsinki: Sosiaali- ja terveysministeriö \& Kansanterveyslaitos. 47 pp. ISBN 952-00-2130-2. Accessed on Dec. 7, 2007. Available online at http://www.stm.fi/Resource.phx/publishing/store/2006/12/pr1167910102725/passthru. pdf. Sum. in Fin., Swe., and Eng.

Kunst, Anton E., Vivian Bos, Otto Andersen, Mario Cardano, Giuseppe Costa, Seeromanie Harding, Örjan Hemström, Richard Layte, Enrique Regidor, Alison Reid, Paula Santana, Tapani Valkonen, and Johan P. Mackenbach. 2004. Monitoring of trends in socioeconomic inequalities in mortality: experiences from a European project. Demographic Research Special Collection 2 (Article 9):232-54. Accessed on March. 7, 2008. Available online at http://www.demographic-research.org/special/2/9/s2-9.pdf

Laatikainen, Tiina, Julia Critchley, Erkki Vartiainen, Veikko Salomaa, Matti Ketonen, and Simon Capewell. 2005. Explaining the decline in coronary heart disease mortality in Finland between 1982 and 1997. American Journal of Epidemiology 162(8):764-73.

Lahti, Raimo A. 2005. From findings to statistics: an assessment of Finnish medical cause-of-death information in relation to underlying-cause coding. Helsinki: University of Helsinki. 81 pp + appendices.ISBN 952-91-9449-8. Accessed on Dec. 27, 2007. Available online at http://ethesis.helsinki.fi/julkaisut/laa/oikeu/vk/lahti/fromfind.pdf. Doctoral dissertation.

Lehtonen, Aapo, Veikko Salomaa, Pirjo Immonen-Räihä, Cinzia Sarti, Markku Mähönen, Jaakko Tuomilehto, Jorma Torppa, and Juhani Sivenius. 2004. Declining incidence and mortality of stroke in persons aged $>=75$ years in Finland; the FINSTROKE study. European Journal of Cardiovascular Prevention \& Rehabilitation 11(6):466-70. 
Lyyra, Tiina-Mari and Eino Heikkinen. 2006. Kuolleisuuden ennustetekijät Ikivihreätprojektin osatutkimuksissa [Predictors of mortality in the Evergreen research project]. Gerontologia 20(3):118-9.

Lyyra, Tiina-Mari and Riitta-Liisa Heikkinen. 2006. Perceived social support and mortality in older people. The Journals of Gerontology Series B: Psychological Sciences and Social Sciences 61(3):147-52.

Lyyra, Tiina-Mari. 2006. Predictors of mortality in old age: contribution of self-rated health, physical functions, life satisfaction and social support on survival among older people. Studies in sport, physical education and health, No. 119. Jyväskylä: University of Jyväskylä. 72, [40] pp. ISBN 951-39-2611-7. Accessed on Dec. 10, 2007. Available online at http://dissertations.jyu.fi/studsport/9513926567.pdf. Doctoral dissertation.

Lyyra, Tiina-Mari, Timo M. Törmäkangas, Sanna Read, Taina Rantanen, and Stig Berg. 2006. Satisfaction with present life predicts survival in octogenarians. The Journals of Gerontology Series B: Psychological Sciences and Social Sciences 61(6):319-26.

Lönnqvist, Jouko. 2005. Itsemurhat [Suicides]. Pp. 185-89 in Suomalaisten terveys, edited by Arpo Aromaa, Jussi Huttunen, Seppo Koskinen, and Juha Teperi. Helsinki: Duodecim \& KTL \& STAKES.

Mackenbach, J.P., M. Huisman, O. Andersen, M. Bopp, J.K. Borgan, C. Borrell, G. Costa, P. Deboosere, A. Donkin, S. Gadeyne, C. Minder, E. Regidor, T. Spadea, T. Valkonen, and A.E. Kunst. 2004. Inequalities in lung cancer mortality by the educational level in 10 European populations. European Journal of Cancer 40:126-35.

Manderbacka, Kristiina, Tiina Hetemaa, Ilmo Keskimäki, Pekka Luukkainen, Seppo Koskinen, and Antti Reunanen. 2006. Are there socioeconomic differences in myocardial infarction event rates and fatality among patients with angina pectoris? Journal of Epidemiology and Community Health 60(5):442-7.

Martelin, T., P. Mäkelä, and T. Valkonen. 2004. Contribution of deaths related to alcohol or smoking to the gender difference in life expectancy. European Journal of Public Health 14(4):422-27.

Martelin, Tuija, Seppo Koskinen, and Tapani Valkonen. 2005. Kuolleisuus [Mortality]. Pp. 117-29 in Suomalaisten terveys, edited by Arpo Aromaa, Jussi Huttunen, Seppo Koskinen, and Juha Teperi. Helsinki: Duodecim \& KTL \& STAKES.

Martikainen, P., N. Mäki, and J. Blomgren. 2004. The effects of area and individual social characteristics on suicide risk: a multilevel study of relative contribution and effect modification. European Journal of Population 20(4):323-50.

Martikainen, Pekka and Petteri Sipilä. 2005. Immediate communities and individual sociodemographic disadvantage - a study of the effects of area and individual characteristics on health and cause-specific mortality. Pp. 44-53 in Gems of the Health Promotion Research Programme, edited by [Marika Javanainen]. Helsinki: Cancer Society of Finland \& Academy of Finland. Published also in Finnish. 
Martikainen, Pekka, Tuija Martelin, Elina Nihtilä, Karoliina Majamaa, and Seppo Koskinen. 2005. Differences in mortality by marital status in Finland from 1976 to 2000: analyses of changes in marital-status distributions, socio-demographic and household composition, and cause of death. Population Studies 59(1):99-115.

McMichael, A.J., M. McKee, V. Shkolnikov, and T. Valkonen. 2004. Mortality trends and setbacks: global convergence or divergence? Lancet 363(9415):1155-59.

Mäkelä, P., P. Martikainen, and E. Nihtilä. 2005. Temporal variation in deaths related to alchohol intoxication and in drinking. International Journal of Epidemiology $34(765-771)$.

Notkola, Veijo. 2004. Namibia ennen aidsia ja sen puhkeamisen jälkeen [Namibia before AIDS and after its outbreak]. Pp. 233-43 in Vertailevan tutkimuksen ulottuvuuksia, edited by Risto Alapuro and Ilkka Arminen. Helsinki: WSOY.

Näyhä, Simo. 2005. Kylmä, kuuma ja kuolleisuus [Cold, hot, and mortality]. Duodecim 121:433-9.

Pajunen, Pia, Jorma Torppa, Mauno Huohvanainen, Veikko Salomaa, and Erkki Vartiainen. 2004. Sepelvaltimotautikuolleisuuden itä-länsiero kaventunut miehillä 30 vuoden seuranta-aikana [The difference in coronary heart disease mortality among men from eastern and western Finland has decreased over the past 30 years ]. Suomen Lääkärilehti 59(51-52):5013-16.

Pelkonen, Margit. 2006. The relationship of smoking habits, physical activity and chronic bronchitis to pulmonary function and of pulmonary function and chronic bronchitis to mortality: a 40 year follow-up in middle-aged men. Kuopion yliopiston julkaisuja. D, Lääketiede, No. 380. Kuopio: University of Kuopio. 80, [41] pp. ISBN 951-27-0560-5. Accessed on Dec. 10, 2007. Available online at http://www.uku.fi/vaitokset/2006/isbn951-27-0560-5.pdf

Pensola, Tiina and Pekka Martikainen. 2004. Life course experiences and mortality by adult social class among young men. Social Science \& Medicine 58(11):2149-70. Pensola, Tiina, Hilkka Ahonen, and Veijo Notkola. 2004. Ammatitja kuolleisuus: työllisten ja työttömien ammattiryhmittäinen kuolleisuus 1996-2000 = yrken och dödlighet: yrkesmässig dödlighet för sysselsatta och arbetslösa 1996-2000 [Occupations and mortality: mortality by occupation of the employed and unemployed 1996-2000]. Helsinki: Tilastokeskus \& Kuntoutussäätiö. 101 pp. ISBN 952-467-352-5. Sum. in Swe.

Pesonen, Tuula M., Ulrich Tacke, Kari O. Karkola, Jukka Hintikka, and Johannes Lehtonen. 2004. Gender-related changes in suicide rates and methods in Eastern Finland from 1988 to 1997. Nordic Journal of Psychiatry 58(4):327-32.

Saarela, Jan, and Fjalar Finnäs. 2005 . Mortality inequality in two native population groups. Population Studies 59(3):313-20.

Saarnio, Pekka. 2005. Alkoholistien kuolleisuus - tulokset kuudentoista vuoden seurannasta [Mortality of alcoholics - results of the sixteen-year follow-up study]. Duodecim 121:2099-103. 
Sailas, Jukka. 2004. Alkoholin, tupakan ja huumausaineiden aiheuttama sairauskuormitus maailmassa [Global burden of disease attributable to alcohol, tobacco and other psychoactive substances]. Pp. 68-80 in Tommi 2004: Alkoholi- ja huumetutkimuksen vuosikirja. Helsinki: Alkoholi- ja huumetutkijain seura. Accessed on Dec. 7, 2007. Available online at http://www.ahts.fi/index.php?option=com content\&task=view\&id=31\&Itemid=49 Sum. in Eng.

Shkolnikov, Vladimir M., Alexander D. Deev, Øystein Kravdal, and Tapani Valkonen. 2004. Educational differentials in male mortality in Russia and northern Europe: a comparison of an epidemiological cohort from Moscow and St. Petersburg with male populations of Helsinki and Oslo. Demographic Research 10(Article 1):ii, 1-26. Accessed on Oct. 26, 2006. Available online at http://www.demographic-research.org/Volumes/Vol10/1/default.htm

Sivenius, Juhani, Jaakko Tuomilehto, Pirjo Immonen-Räihä, Minna Kaarisalo, Cinzia Sarti, Jorma Torppa, Kari Kuulasmaa, Markku Mähönen, Aapo Lehtonen, and Veikko Salomaa. 2004. FINSTROKE-tutkimus: Aivohalvauksen ilmaantuvuus ja kuolleisuus laskivat Suomessa vuosina 1983-1997 [Continuous 15-year decrease in incidence and mortality of stroke in Finland: the FINSTROKE study]. Suomen Lääkärilehti 59(2729):2863-688. Sum in Eng.

Vahtera, Jussi, Jaana Pentti, and Mika Kivimäki. 2004. Sickness absence as a predictor of mortality among male and female employees. Journal of Epidemiology \& Community Health 58(4):321-6.

Vahtera, Jussi, Mika Kivimäki, Jaana Pentti, Anne Linna, Marianna Virtanen, Pekka Virtanen, and Jane E. Ferrie. 2004. Organizational downsizing, sickness absence, and mortality: 10-town prospective cohort study. British Medical Journal 328(7439):555-7.

Vahtera, Jussi, Mika Kivimäki, Ari Väänänen, Anne Linna, Jaana Pentti, Hans Helenius, and Marko Elovainio. 2006. Sex differences in health effects of family death or illness: are women more vulnerable than men? Psychosomatic Medicine 68(2):283-91.

Valkonen, Tapani, Pekka Martikainen, and Jenni Blomgren. 2004. Increasing excess mortality among non-married elderly people in developed countries. Demographic Research Special Collection 2(Article 12):305-30. Accessed on Nov. 14, 2006. Available online at http://www.demographic-research.org/special/2/12/default.htm

Valkonen, Tapani and Timo Kauppinen. 2005. Märkä ja nuorena nukkuva sukupolvi? [A generation prone to alchol and dying young?]. Pp. 334-46 in Suuret ikäluokat, edited by Antti Karisto. Tampere: Vastapaino.

Valkonen, Tapani and Pekka Martikainen. 2006. Trends in life expectancy by level of education and occupational social class 1981-2000. Finnish Yearbook of Population Research 42(2006):27-42.

Valkonen, Tapani. 2006. Social inequalities in mortality. Pp. 195-206 in Demography: analysis and synthesis, edited by Graziella Caselli, Jacques Vallin, and Guillaume 
Wunsch. Amsterdam: Elsevier.

Van Lenthe, F.J., L.N. Borrell, G. Costa, A.V. Diez Rouax, T.M. Kauppinen, C. Marinacci, P. Martikainen, E. Regidor, M. Stafford, and T. Valkonen. 2005. Neighbourhood unemployment and all-cause mortality: a comparison of six countries. Journal of Epidemiology and Community Health 59(3):231-37.

\section{F. FERTILITY}

Apter, Dan, Osmo Kontula, Marketta Ritamies, Rita Siegberg, and Outi Hovatta. 2005. Seksuaaliterveys [Sexual health]. Pp. 84-88 in Suomalaisten terveys, edited by Arpo Aromaa, Jussi Huttunen, Seppo Koskinen, and Juha Teperi. Helsinki: Duodecim \& KTL \& STAKES.

Apter, Dan, Osmo Kontula, Marketta Ritamies, Rita Siegberg, and Outi Hovatta. 2006. Sexual health. Pp. 34-35 in Health in Finland, edited by Seppo Koskinen Arpo Aromaa, Jussi Huttunen, and Juha Teperi. Helsinki: National Public Health Institute KTL \& STAKES National Research and Development Centre for Welfare and Health $\&$ Ministry of Social Affairs and Health.

Bajos, Nathalie, Agnès Guillaume, and Osmo Kontula. 2004. Le comportement des jeunes Européens face à la santé génésique. Volume 1. Etudes démographiques. 42. Strasbourg: Conseil de l'Europe. 150 pp. ISBN 92-871-5471-6. English version in 2003.

Degni, Filio. 2005. The social and cultural determinants of the use of contraception among married Somali women living in Finland. Research Report, No. 148. 2. rev. ed. Helsinki: Stakes National Research and Development Centre for Welfare and Health. 135 pp. ISBN 951-33-1736-6. Doctoral dissertation.

Degni, F., L. Koivusilta, and A. Ojanlatva. 2006. Attitudes towards and perceptions about contraceptive use among married refugee women of Somali descent living in Finland. European Journal of Contraception and Reproductive Health Care 11(3):190-6.

Forssén, Katja and Veli-Matti Ritakallio. 2005. Ensimmäisen lapsen hankinta [Having one's first child]. Pp. 31-42 in Perheiden munttuvat elinolot: artikkeleita lapsiperheiden elämänmuutoksista, edited by Henna Isoniemi and Irmeli Penttilä. Tutkimuksia, No. 243. Helsinki: Tilastokeskus.

Forsssén, K. and V.-M. Ritakallio. 2006. First births: a comparative study of the patterns of transition to parenthood in Europe. Pp. 161-77 in Social policy, employment and family change in comparative perspective, edited by J. Bradshaw and A. Hatland. Cheltenham: Edward Elgar Publishing.

Gissler, Mika. 2004. Synnytykset ja raskaudenkeskeytykset [Deliveries and abortions]. Pp. 17-28. Sum. in Eng. in Näkökulmia nuorten seksuaaliterveyteen, edited by Elise Kosunen and Maija Ritamo. Raportteja, No. 282. Helsinki: STAKES Sosiaali- ja terveysalan tutkimus- ja kehittämiskeskus.

Gissler, Mika and Hanna Eronen. 2004. Raskaudenkeskeytykset hienoisessa laskussa [The number of abortions have a slightly downward trend]. Kätilölehti(5):180-83. Gissler, Mika and Annukka Ritvanen. 2004. Lisääntymisterveys tilastona [Reproductive health as statistics]. Terveydenhoitaja(3):30-31. 
Gissler, Mika, Annukka Ritvanen, and Elina Hemminki. 2004. Nuori nainen on vanha synnyttäjä [A young woman is an old parturient]. Terveydenhoitaja(3):24-27.

Haimi, Olavi. 2004. Suuret ikäluokat ja asutustoiminta [Baby boom cohorts and settlement]. Yhteiskuntapolitiikka 69(1):72-76.

Hassani, Kobra Falah, Elise Kosunen, and Arja Rimpelä. 2006. The use of oral contraceptives among Finnish teenagers from 1981 to 2003. Journal of Adolescent Health 39(5):649-55.

Hinkula, Marianne, Eero Pukkala, Pentti Kyyrönen, and Antti Kauppila. 2006. Incidence of ovarian cancer of grand multiparous women - a population-based study in Finland. Gynecologic Oncology 10(1):207-11.

Kautto, Mikko. 2004. Entä jos syntyvyys muuttuisi? [If fertility would change?] Pp. 51-58 in Väestökehitykseen vaikuttaminen - tulisiko syntyvyyttä ja maahanmuuttoa lisätä? Tulevaisuusselonteon liiteraportti 3, edited by Mikko Kautto. Valtioneuvoston kanslian julkaisusarja, No. 31/2004. Helsinki: Valtioneuvoston kanslia. Accessed on March 3, 2008. Available online at http://www.vnk.fi/julkaisukansio/2004/j31-vaestokehitykseen-vaikuttaminen_pdf/fi.pdf

Kesseli, Katja, Elena Regushevskaya, Tatyana Dubikaytis, Svetlana Kirichenko, Anna Rotkirch, Elina Haavio-Mannila, Olga Kutznetsova, Elina Hemminki, and REFER group. 2005. Reproductive health and fertility in St. Petersburg: report on a survey of 18-44 year old women in 2004. Working papers, Department of Sociology, No. 60. Helsinki: University of Helsinki \& STAKES National Research and Development Centre. 164, [2] pp. ISBN 952-10-2496-8. Accessed on Nov. 29, 2007. Available online at http://groups.stakes.fi/NR/rdonlyres/4DA18B28-4913-4584-BD50-5192425A39DD/0/ WomenSurveyStP04 english.pdf Also in Russian.

Kirkkola, Anna-Leena. 2005. Family planning: with focus on contraception as seen by health centre physicians and population. Acta Universitatis Tamperensis, No. 989. Tampere: Tampere University Press. 85, [89] pp. ISBN 951-44-5897-4. Accessed on Dec. 3, 2007. Available online at http://acta.uta.fi/pdf/951-44-5898-2.pdf. Doctoral dissertation.

Kirkkola, Anna-Leena, Kari Mattila, and Irma Virjo. 2005. Problems with condoms - a population-based study among Finnish men and women. European Journal of Contraception and Reproductive Health Care 10(2):87-92.

Klemetti, Reija, Sinikka Sihvo, and Päivikki Koponen. 2004. Tahaton lapsettomuus ja hedelmöityshoidot [Involuntary childlessness and fertility treatments]. Pp. 45-53 in Lisääntymisterveys Suomessa: Terveys 2000 -tutkimus, edited by Päivikki Koponen and Riitta Luoto. Kansanterveyslaitoksen julkaisuja, B4/2004. Helsinki: Kansanterveyslaitos, Terveyden ja toimintakyvyn osasto.

Kontula, Osmo. 2004. Trends in teenage sexual behavior and births in Europe. Yearbook of Population Research in Finland 40:133-151.

Kontula, Osmo. 2004. Reproductive health behavior of young Europeans. Volume 2: the role of education and information. Population studies. No. 45. Strasbourg: Council of Europe Publishing. 99 pp. ISBN 92-871-5456-2. 
Kontula, Osmo. 2004. Tendances des comportements sexuels chez les adolescents: grossesses, maladies sexuellement transmissibles et infection par le VIH en Europe. Pp. 79147 in Le comportement des jeunes Européens face à la santé génésique. Volume 1. Etudes démographiques. 42. Strasbourg: Conseil de l'Europe. English version in 2003.

Kontula, Osmo. 2006. Hallazgos sobre la conducta sexual juvenil, los embarazos y los nacimentos en Europa: el rol de la educación en la salud sexual [Findings in sexual behavior, pregnancies and births among young people in Europe: the role of education and information on sexual health]. Ediciones Universidad Católica del Norte. Pp. 2961 in Construyendo una agenda temática en sexualidad, edited by Jaime Barrientos. Antofagasta, Chile: Universidad Católica del Norte.

Koponen, Päivikki, Marja-Liisa Lindbohm, and Sinikka Sihvo. 2004. Raskaudet, synnytykset, keskenmenot ja keskeytykset [Pregnancies, deliveries, miscarriages, and abortions]. Pp. 27-33 in Lisääntymisterveys Suomessa: Terveys 2000 -tutkimus, edited by Päivikki Koponen and Riitta Luoto. Kansanterveyslaitoksen julkaisuja B5/2004. Helsinki: Kansanterveyslaitos, Terveyden ja toimintakyvyn osasto.

Kosunen, Elise, Sinikka Sihvo, Minna Nikula, and Elina Hemminki. 2004. Raskauden ehkäisy [Contraception]. Pp. 54-61 in Lisääntymisterveys Suomessa: Terveys 2000 -tutkimus, edited by Päivikki Koponen and Riitta Luoto. Kansanterveyslaitoksen julkaisuja B5/2004. Helsinki: Kansanterveyslaitos, Terveyden ja toimintakyvyn osasto.

Kosunen, Elise. 2005. Opiskeluikäisten raskaudenkeskeytykset lisääntyvät [Abortion rate among students are increasing]. Duodecim 121:2253-4.

Kotkavuori, Jouni. 2004. Aikapommi nimeltä puuttuvat tytöt [The time bomb: missing girls]. Tietoaika(6-7):18-22.

Leppäluoto, Juhani. 2005. Valo ja hedelmällisyys [Light and fecundity]. Duodecim 121(23):2551-6.

Leppämäki, Henna. 2006. Puolalainen aborttikeskustelu [The Polish abortion discussion]. Idäntutkimus(4):44-59

Luoto, Riitta, Tarja I. Kinnunen, Päivikki Koponen, Risto Kaaja, Satu Männistö, and Erkki Vartiainen. 2004. Naisten lisääntymisterveys Suomessa: tuloksia FINRISKI 2002 -tutkimuksesta [Reproductive health in Finland -results from the FINRISKI 2002 study]. Suomen Lääkärilehti 59(9):885-90. Sum. in Eng.

Miettinen, Anneli and Pirjo Paajanen. 2005. Yes, no, maybe: fertility intentions and reasons behind them among childless Finnish men and women. Yearbook of Population Research in Finland 41:165-84.

Nieminen, Mauri. 2006. Korkea syntyvyys takaa Yhdysvaltain väestönkasvun [High fertility guarantees the population growth of the United States]. Tieto \& Trendit (9):45-8.

Oksama, Heidi, Sinikka Sihvo, and Kirsi Pietilä. 2004. Jälkiehkäisy itsehoitona: käyttäjäkysely apteekin asiakkaille [Over-the-counter emergency contraception use: a survey]. Suomen Lääkärilehti 59(46):4507-11. 
Paajanen, Pirjo. 2005. Women and postponing childbearing in Finland. Pp. 45-58 in Contributions from PPAS at the European Population Conference, Warsaw, Poland, 2630 August 2003. No. 3, 2005. Wiesbaden: Federal Institute for Population Research.

Perheentupa, Antti. 2004. Raskaudenehkäisy imetysaikana [Contraception during lactation]. Duodecim 120:1467-73.

Raatikainen, Kaisa, Nonna Heiskanen, and Seppo Heinonen. 2005. Marriage still protects pregnancy. BJOG: An International Journal of Obstetrics and Gynaecology 112(10):1411-6.

Raatikainen, Kaisa, Nonna Heiskanen, and Seppo Heinonen. 2006. Induced abortion: not an independent risk factor for pregrancy outcome, but a challenge for health counselling. Annals of Epidemiology 16(8):587-92.

Ritamies, Marketta. 2006. Sinappikylvystä ehkäisypilleriin: suomalaisen perhesuunnittelun historia [From mustard bath to contraceptive pill: history of Finnish family planning]. Väestöntutkimuslaitoksen julkaisusarja D 44. Helsinki: Väestöliitto, Väestöntutkimuslaitos. 331 pp. ISBN 951-9450-41-6.

Rotkirch, Anna. 2004. Pienentyvien perheiden arvoitus [The mystery of families becoming smaller]. Idäntutkimus 11(3):48-53.

Sauli, Hannele. 2004. Lapsiperheetkin ikääntyvät [Also families with children are aging]. Hyvinvointikatsaus(4):4-10.

Shemeikka, Riikka and Paula Alkio. 2004. Aids Afrikassa [AIDS in Africa]. Väestötietosarja. 12. Helsinki: Väestöliitto. 32 pp. ISBN 951-9450-03-3.

Shemeikka, R. and V. Notkola. 2005. Fertility reduction caused by HIV/AIDS and its demographic impact in northern Namibia. Pp. 207-26 in What are we doing there? experiences and lessons learned from development cooperation in health care and social welfare (1990-2005), edited by Ursula Aaltonen and Simo Mannila. Helsinki: STAKES National Research and Development Centre for Welfare and Health.

Shemeikka, R., V. Notkola, and H. Siiskonen. 2005. Fertility decline in North-Central Namibia: an assessment of fertility in the period 1960-2000 based on parish registers. Demographic Research 13(Article 4):83-116. [cited on Nov. 16, 2006]. Available online at http://www.demographic-research.org/Volumes/Vol13/4/default.htm

Shemeikka, Riikka. 2006. Fertility in Namibia: changes in fertility levels in NorthCentral Namibia 1960-2001, including an assessment of the impact of HIV. Yearbook of Population Research in Finland, Vol. 42. Supplement. Helsinki: Väestöliitto, The Population Research Institute. 226 pp. ISBN 951-9450-44-0. Doctoral dissertation.

Toivanen, Riikka, Sirpa Vilska, and Maija Tulppala. 2004. Sylillinen surua - lapsettomuuden kokemus [Experiencing infertility]. Suomen Lääkärilehti 59(43):4115-20.

Vikat, Andres. 2004. Raskauksien sosioekonomiset ja alueelliset erot [The socioeconomic and regional differences in abortions]. Pp. 29-40. Sum. in Eng. in Näkökulmia 
nuorten seksuaaliterveyteen, edited by Elise Kosunen and Maija Ritamo. Raportteja, No. 282. Helsinki: STAKES Sosiaali- ja terveysalan tutkimus- ja kehittämiskeskus.

Vikat, Andres, Elizabeth Thomson, and Alexia Prskawetz. 2004. Childrearing responsibility and stepfamily fertility in Finland and Austria. European Journal of Population 20(1):1-21.

Vikat, Andres. 2004. Syntyvyyteen vaikuttavat tekijät [Factors which affect fertility]. Pp. 20-30 in Väestökehitykseen vaikuttaminen - tulisiko syntyvyyttä ja maahanmuuttoa lisätä? Tulevaisuusselonteon liiteraportti 3. Valtioneuvoston kanslian julkaisusarja, No. 31/2004 Helsinki: Valtioneuvoston kanslia. Accessed on March 7, 2008. Available online at http://www.vnk.fi/julkaisukansio/2004/j31-vaestokehitykseen-vaikuttaminen_pdf/fi.pdf

Virtala, Aira and Irma Virjo. 2004. University students seeking hormonal emergency contraception: why do they not want pregrancy now? When is it suitable to have children. Yearbook of Population Research in Finland 40:119-31.

Virtala, Aira and Irma Virjo. 2005. Consultations concerning contraception and induced abortions among university students - trends in Finland 1986-2003. Contraception 72(5):372-6.

Virtala, Aira and Kristina Kunttu. 2006. Jäävätkö yliopisto-opiskelijoiden toiveet lasten saamisesta haaveeksi? [Childbearing among university students - will the dream remain a dream?]. Suomen Lääkärilehti 61(1-2):27-32.

\section{G. NUPTIALITY AND THE FAMILY}

Akar, Sylvia and Marja Tiilikainen. 2004. Katsaus islamilaiseen maailmaan: naiset, perhe ja seksuaaliterveys [Report on islamic world: women, family, and sexual health]. Väestötietosarja, No. 13. Helsinki: Väestöliitto. 24, [1] pp. ISBN 951-9450-08-4. Accessed online on Dec. 3, 2007. Available online at

http://www.vaestoliitto.fi/mp/db/file library/x/IMG/12147/file/Katsausislamilaiseenmaailmaan.pdf

Haavio-Mannila, Elina and Anna Rotkirch. 2004. Ydin- ja versoperheet Suomessa ja Pietarissa [Nuclear families and extended and multiple family households in Finland and St. Petersburg]. Pp. 165-82 in Vertailevan tutkimuksen ulottuvuuksia, edited by Risto Alapuro and Ilkka Arminen. Helsinki: WSOY.

Heikkilä, Elli. 2004. Monikulttuuriset avioliitot sillanrakentajina [Multicultural marriages as bridge builders]. Pp. 3-6 in Monikulttuuriset avioliitot sillanrakentajina, edited by Elli Heikkilä, Ritva Viertola-Cavallari, Päivi Oksi-Walter, and Jonna Roos. Web Reports. 2. Turku: Siirtolaisuusinstituutti \& Ulkosuomalaisparlamentti. Accessed online on Oct., 18, 2007.Available online at http://www.migrationinstitute.fi/pdf/webreports2.pdf

Heikkilä, Elli. 2005. Monikulttuuriset avioliitot tilastoissa ja arjen elämässä [Multicultural marriages in statistics and everyday life]. Pp. 24-36 in Olemme munttaneet: näkökulmia maahanmuuttoon, perheiden kotoutumiseen ja ammatillisen työn käytän- 
töihin, edited by Anne Alitolppa-Niitamo, Ismo Söderling, and Stina Fågel. Helsinki: Väestöliitto, Väestöntutkimuslaitos \& [Väestöliiton] Kotipuu.

Härkönen, Juho. 2005. Divorce risk factors across Finnish marriage cohorts, 19541989. Yearbook of Population Research in Finland 41:151-64.

Isoniemi, Henna. 2005. Nuorten aikuisten muutto pois lapsuudenkodista [The moving of young adults from the childhood home]. Pp. 63-84 in Perheiden muuttuvat elinolot: artikkeleita lapsiperheiden elämänmuutoksista, edited by Henna Isoniemi and Irmeli Penttilä. Research Reports, No. 243. Helsinki: Statistics Finland.

Järvinen-Tassopoulos, Johanna. 2004. Challenging differences: the case of the GreekFinnish marriage. Siirtolaisuus = Migration 31(3):12-21.

Järvinen-Tassopoulos, Johanna. 2004. Kreikkalais-suomalainen avioliitto: neuvottelua kahden kulttuurin leikkauspisteessä [Greek-Finnish marriage: negotiation at the intersection of two cultures]. Pp. 28-34 in Monikulttuuriset avioliitot sillanrakentajina, edited by Elli Heikkilä, Ritva Viertola-Cavallari, Päivi Oksi-Walter, and Jonna Roos. Turku: Siirtolaisuusinstituutti \& Ulkosuomalaisparlamentti. Accessed online on Oct. 19, 2007. Available online at http://www.migrationinstitute.fi/pdf/webreports2.pdf

Ketokivi, Kaisa. 2004. Pidentynyt nuoruus ja perheen perustaminen: individualistisen elämänorientaation jäljillä [Extended youth and family formation: tracing the individualistic life orientation]. Sosiologia(2):94-107.

Ketokivi, Kaisa. 2005. Aikuistumisen ja perheen perustamisen ristiriidat pidentyneessä nuoruudessa [Contradictions of becoming an adult and founding one's own family in the context of prolonged youth]. Pp. 100-37. in Polkuja ja poikkeamia - aikuisuutta etsimässä, edited by Sinikka Aapola and Kaisa Ketokivi. Julkaisuja, No. 56. Helsinki: Nuorisotutkimusverkosto \& Nuorisotutkimusseura.

Kukko, Heikki. 2006. Asuntokuntien koon kehitys Suomessa - suurperheistä yksinasujiksi [Change of the size of household-dwelling units in Finland-from large family to single person unit]. Pellervon taloudellisen tutkimuslaitoksen työpapereita No. 82. Helsinki: Pellervon taloudellinen tutkimuslaitos. 62, [5] pp. ISBN 952-5594-19-X. Accessed on Jan. 16, 2008. Available online at http://www.ptt.fi/dokumentit/tp82 08080615.pdf.

Leinonen, Johanna. 2004. Suomalaisten siirtolaisnaisten avioliitot Pohjois-Amerikassa toisen maailmansodan jälkeen [The marriages of Finnish emigrant women in North America after World War II]. Pp. 35-45 in Monikulttuuriset avioliitot sillanrakentajina, edited by Elli Heikkilä, Ritva Viertola-Cavallari, Päivi Oksi-Walter, and Jonna Roos. Web Reports, No. 2. [Accessed online on Oct. 19, 2007]. Turku: Siirtolaisuusinstituutti \& Ulkosuomalaisparlamentti. Available online at http://www.migrationinstitute.fi/pdf/webreports2.pdf

Melby, Kari, Anu Pylkkänen, Bente Rosenbeck, and Christina Carlsson. 2006. The Nordic model of marriage. Women's History Review 15(4):651-61. 
Moisio, Pasi. 2005. Lapsiperheet Suomessa [Finnish families with children]. Pp. 9-15 in Lapsiperheiden taloudellisen tilanteen kehitys Suomessa 1990-2002, edited by Pasi Moisio: STAKES Sosiaali- ja terveysalan tutkimus- ja kehittämiskeskus. Raportteja, No. 4/2005. Helsinki: STAKES Sosiaali- ja terveysalan tutkimus- ja kehittämiskeskus. Accessed on Jan. 16, 2008. Available online at http://www.stakes.fi/verkkojulkaisut/raportit/Ra4-2005.pdf.

Oinonen, Eriikka. 2004. Finnish and Spanish families in converging Europe. Tampere: University of Tampere. Acta Electronica Universitatis Tamperensis, No. 381.317 pp. Accessed online on Oct. 10, 2007.. ISBN 951-44-6093-6. Available online at http://acta.uta.fi/pdf/951-44-6093-6.pdf. Doctoral dissertation.

Oinonen, Eriikka. 2004. Starting the first family: changes in patterns of family formation and demographic trends in Finland and Spain. European Societies 6(3):319-46.

Paajanen, Pirjo. 2005. Perhebarometri 2005: eri teitä vanhemmuuteen - kaksikymppisenä ja kolmekymppisenä lapsen saaneiden näkemyksiä perheellistymisestä ja vanhemmuudesta [Family survey 2005: different roads to parenthood - views of men and women who have become parents in their twenties and thirties]. Katsauksia E, No. 21/2005. Helsinki: Väestöliitto, Väestöntutkimuslaitos. 95 pp. ISBN 951-9450-28-9.

Paajanen, Pirjo. 2006. Perhebarometri 2006: päivisin leiväntuoja, iltaisin hoiva-isä: alle 3-vuotiaiden esikoislasten isien näkemyksiä ja kokemuksia isyydestä [Family survey 2006: breadwinner during the day, caring father in the evening: under 3-year-old firstborns' fathers' views and experiences of fatherhood]. Katsauksia E, No. 24/2006. Helsinki: Väestöliitto, Väestöntutkimuslaitos. 105 pp. ISBN 951-9450-53-X.

Pesälä, Leena. 2004. When one does not want to be like others: the basis of the sense of control among conservative Laestadian mothers with large families. Yearbook of Population Research in Finland 40:153-171.

Viertola-Cavallari, Ritva. 2004. Seka-avioliitot yhteiskunnallisena katalysaattorina [Mixed marriages as a social catalyzer]. Pp. 8-21 in Monikulttuuriset avioliitot sillanrakentajina, edited by Elli Heikkilä, Ritva Viertola-Cavallari, Päivi Oksi-Walter, and Jonna Roos. Web Reports. 2. Turku: Siirtolaisuusinstituutti \& Ulkosuomalaisparlamentti. Accessed online on Oct. 18, 2007. Available online at http://www.migrationinstitute.fi/pdf/webreports2.pdf 


\section{H. MIGRATION}

\section{International migration}

Alanen, Aku. 2006. Etelä-Suomi ja rajamaakunnat vetävät venäläisiä [Southern Finland and border provinces draw Russians]. Tieto \& Trendit (3):58-61.

Björklund, Krister. 2005. Finns over the Atlantic: an overview of the emigration from Finland to North America. Turku: Institute of Migration. 22 pp. ISBN 951-9266-82-8.

Ervasti, Heikki. 2004. Attitudes towards foreign-born settlers: Finland in a comparative perspective. Yearbook of Population Research in Finland 40:25-44.

Forsander, Annika. 2004. Maahanmuuton merkitys väestökehityksen kannalta [The importance of immigration considering population development]. Pp. 59-133 in Väestökehitykseen vaikuttaminen - tulisiko syntyvyyttä ja maahanmuuttoa lisätä? Tulevaisuusselonteon liiteraportti 3, edited by Mikko Kautto. Valtioneuvoston kanslian julkaisusarja, No. 31/2004. Helsinki: Valtioneuvoston kanslia. Accessed online on March 3, 2008. Available online at

http://www.vnk.fi/julkaisukansio/2004/j31-vaeestoekehitykseen-vaikuttaminen_pdf/fi.pd

Forsander, Annika, Mika Raunio, Perttu Salmenhaara, and Mika Helander. 2004. Sykettä ja suvaitsevaisuutta: globaalin osaamisen kansalliset rajat [Pulse and tolerance: the national borders of global skill]. SITRA, No. 262. Helsinki: Edita. 244 pp. ISBN 951-37-4174-5.

Hakamies, Pekka. 2005. Introduction: migration and local identity in former territories of the USSR. Pp. 9-18 in Moving in the USSR: Western anomalies and Northern wilderness, edited by Pekka Hakamies. Studia Fennica Historica, No. 10. Helsinki: Finnish Literature Society.

Hautala, Johanna and Petteri Toivonen. 2005. Ulkomaalaiset huippuosaajat ja heidän puolisonsa Oulussa [Foreign top professionals and their spouses in Oulu] . Pp. 43-54 in Kansainvälistyvä Oulu - monikulttuurinen Oulu?, edited by Jussi S. Jauhiainen and Katri Suorsa. Nordia Tiedonantoja, No. 1/2005.Oulu: Pohjois-Suomen maantieteellinen seura \& Oulun yliopiston maantieteen laitos.

Heikkilä, Elli and Taru Järvinen. 2004. Muuttoliike Suomen ja Itämeren maiden välillä [Migration between Finland and the Baltic states]. Talous \& Yhteiskunta(1):13-17.

Heikkilä, Elli. 2006. Human migration and itse effects on regional development - from global to local. Siirtolaisuus $=$ Migration 33(4):1-5.

Hokkanen, Mari. 2004. Ulkomaalaishallinto eräissä Euroopan maissa [Immigration administration in some European countries]. Sisäasiainministeriön julkaisuja, No. 33/2004. Helsinki: Sisäasiainministeriö. 32, [2] pp. ISBN 951-734-736-7. Accessed on Jan. 11, 2008. Available online at

http://www.intermin.fi/intermin/biblio.nsf/vwByTema/ 937A3A88E08E3F86C2256EC40040E0F0?OpenDocument.

Kangaspuro, Markku. 2004. The Soviet depression and Finnish immigrants in Soviet Karelia. Journal of Finnish Studies 8(1):132-40. 
Hyvönen, Heli. 2006. Leaving home behind - career opportunity or seeking for a safer life? A study of Finnish and Estonian migrant women's experiences of immigration. Finnish Yearbook of Population Research 42(2006):129-59.

Hämäläinen, Kari, Aki Kangasharju, Sari Pekkala, and Matti Sarvimäki. 2005. Maahanmuuttajien taloudellinen asema Suomessa [The economic situation of immigrants in Finland]. Talous \& Yhteiskunta(1):33-39.

Hämäläinen, Kari, Aki Kangasharju, Sari Pekkala, and Matti Sarvimäki. 2005. 1990luvun maahanmuuttajien työllisyys, tuloverot ja tulonsiirrot [Immigrants' labor market participation, direct taxes paid, and income transfers in the 1990s]. Työpoliittinen tutkimus. 265. Helsinki: Työministeriö. 108 pp. + 2 appendices. ISBN 951-735-924-1. Accessed on Nov. 30, 2006. Available online at http://www.mol.fi/mol/fi/ $/ 99$ pdf/fi/06 tyoministerio/06 julkaisut/06 tutkimus/tpt265.pdf Sum. in Fin., Swe. and Eng.

Iivari, Juhani. 2006. Tuomittu maahanmuuttaja [A convicted immigrant]. Tutkimuksia, No. 154. Helsinki: STAKES Sosiaali- ja terveysalan tutkimus- ja kehittämiskeskus. 166 pp. ISBN 951-33-1829-X.

Jaakkola, Magdalena. 2005. Suomalaisten suhtautuminen maahanmuuttajiin vuosina 1987-2003 [The attitudes towards immigrants in 1987-2003]. Työpoliittinen tutkimus, No. 286. Helsinki: Työministeriö. 145 pp. ISBN 951-735-969-1. Accessed on Dec. 12, 2006. Available online at http://www.mol.fi/mol/fi/99 pdf/fi/06 tyoministerio/06 julkaisut/06 tutkimus/tpt286.pdf Sum in Fin., Swe., and Eng.

Jaakkola, Magdalena. 2006. Suomalaisten suhtautuminen ulkomaiseen työvoimaan ja pakolaisiin [The Finns' attitudes towards foreign labor and refugees]. Kuntoutus 29(1):5-21.

Jaakkola, Magdalena. 2006. Suomalaisten suhtautuminen ulkomaiseen työvoimaan ja pakolaisiin [The attitudes of Finns towards foreign workers and refugees]. Siirtolaisuus = Migration 33(2):1-12.

Junila, Marianne. 2006. Destinationer för utflyttare från norra Finland på 1960- och 1970-talet [Emigration and its destinations in the inter-Nordic migration during the 1960s and 1970s]. Pp. 75-123 in Mellan majoriteter och minoriteter: om migration, makt och mening, edited by Marianne Junila and Charles Westin. Svenskt i Finland - Finskt i Sverige, Vol. 2. Skrifter utgivna av Svenska litteratursällskapet I Finland. Helsingfors: Svenska litteratursällskapet i Finland. Sum. in Eng.

Junila, Marianne and Charles Westin (ed.). 2006. Svenskt i Finland - finskt i Sverige: mellan majoriteter och minoriteter: om migration, makt och mening [Swedish in Finland - Finnish in Sweden: between majorities and minorities: on migration, power, and meaning]. Skrifter utgivna av Svenska litteratursällskapet I Finland, No. 682: 2. Helsingfors: Svenska litteratursällskapet i Finland. 528 pp. ISBN 951-583-133-4.

Juntto, Anneli. 2005. Maahanmuuttajien asuminen - integroitumista vai segregoitumista? [Housing of the immigrants - integration or segregation]. Pp. 43-58 in Maahanmunttajien elämää Suomessa, edited by Seppo Paananen. Helsinki: Tilastokeskus. 
Karisto, Antti, Pekka Martikainen, Netta Mäki, and Ossi Rahkonen. 2005. Suuren muuton pyörteissä: liikkuvuus ja liikkumattomuus [In the whirl of the great migration: mobility and immobility]. in Suuret ikäluokat, edited by Antti Karisto. Tampere: Vastapaino.

Kautto, Mikko. 2004. Entä jos maahanmuutto muuttuisi? [If immigration would change?]. Pp. 108-17 in Väestökehitykseen vaikuttaminen - tulisiko syntyvyyttä ja maahanmuuttoa lisätä? Tulevaisuusselonteon liiteraportti 3, edited by Mikko Kautto. Valtioneuvoston kanslian julkaisusarja, No. 31/2004. Helsinki: Valtioneuvoston kanslia. Accessed on March 3, 2008.Available online at http://www.vnk.fi/julkaisukansio/2004/j31-vaestokehitykseen-vaikuttaminen_pdf/fi.pdf

Kavén, Pertti. 2003. 70000 pientä kohtaloa: Suomen sotalapset [70000 small fates: Finland's wartime children]. Otalampi: Sahlgrenin kustannusliike Oy. 191, [1] pp. IBSN 951-9016-35-X. 2nd extended edition.

Kepsu, Kaisa. 2006. Finlandssvenska flyttningsmönster och språkgränser [Changing Finland-Swedish migratory patterns and language borders]. Pp. 124-48 in Mellan majoriteter och minoriteter: om migration, makt och mening, edited by Marianne Junila and Charles Westin. Svenskt i Finland - finskt i Sverige, Vol. 2. Skrifter utgivna av Svenska litteratursällskapet i Finland. Helsingfors: Svenska litteratursällskapet i Finland. Sum. in Eng.

Korkiasaari, Jouni. 2005. Finnish North Americans today by statistics. Siirtolaisuus = Migration 32(4):19-21.

Kultalahti, Olli, Ilari Karppi, and Heikki Rantala (ed). 2006. Europe in flux. Vol. 1: transitions and migration pressures. Vol. 1. Migration studies C, No. 16. Turku: Institute of Migration. 285 pp. ISBN 951-9266-87-9.

Lahti-Argutina, Eila. 2004. The fate of Finnish Canadians in Soviet Karelia. Journal of Finnish Studies 8(1):118-31.

Laine, Antti. 2005. Modernisation in the 1940s and 1950s in the part of Karelia that was annexed from Finland on 13 March 1940. Pp. 19-41 in Moving in the USSR: Western anomalies and Northern wilderness, edited by Pekka Hakamies. Studia Fennica Historica, No. 10. Helsinki: Finnish Literature Society.

Lang, Sonja and Ismo Vendelin. 2005. Turvapaikanhakijat ja pakolaiset Oulussa [Asylum seekers and refugees in Oulu]. Pp. 67-78 in Kansainvälistyvä Oulu - monikulttuurinen Oulu?, edited by Jussi S. Jauhiainen and Katri Suorsa. Nordia Tietonantoja, No. 1/2005.Oulu: Pohjois-Suomen maantieteellinen seura \& Oulun yliopiston maantieteen laitos.

Liebkind, Karmela, Simo Mannila, Inga Jasinskaja-Lahti, Magdalena Jaakkola, Eve Kyntäjä, and Anni Reuter. 2004. Venäläinen, virolainen, suomalainen: kolmen maahanmuuttajaryhmän kotoutuminen Suomeen [A Russian, an Estonian, a Finn: the integration of three immigrant groups in Finland]. Helsinki: Gaudeamus. 319 pp. ISBN 951-662-919-9. 
Lähteenmäki, Maria and Hanna Snellman (ed.). 2006. Passages westward. Studia Fennica Ethnologica, No. 9. Helsinki: Finnish Literature Society. 247 pp. ISBN 951746-894-6.

Martikainen, Tuomas. 2005. New Orthodox immigration in Finland. Yearbook of Population Research in Finland 41:117-38.

Martikainen, Tuomas. 2005. Religion, immigrants and integration. AMID Working Paper Series, No. 43/2005. Aalborg: AMID - Akademiet for Migrationsstudier i Danmark. 14 pp. Accessed on Nov. 28, 2006. Available online at http://www.amid.dk/pub/papers/AMID 43-2005 Martikainen.pdf

Martikainen, Tuomas. 2006. Immigrant settlement and religious organisation: the case of Finland. Pp. 335-51 in Religious pluralism in the diaspora, edited by Pratap P. Kumar. International studies in religion and society. Leiden: Brill.

Martikainen, Tuomas. 2006. Maahanmuuttajat ja uskonto: tausta, jäsenyys, yhdyskunnat [Immigrants and religion: background, membership, communities]. Pp. 205240 in Kristinusko Suomessa: Karjalan teologisen seuran, Suomalaisen Teologisen Kirjallisuusseuran ja Joensuun yliopiston symposiumissa marraskuussa 2005 pidetyt esitelmät, edited by Aappo Laitinen. Suomalaisen teologisen kirjallisuuseuran julkaisuja, No. 249. Helsinki: Suomalainen teologinen kirjallisuusseura.

Melegh, Attila, Elena Kondratieva, Perttu Salmenhaara, Annika Forsander, László Hablicsek, and Adrienn Hegyesi. 2004. Globalisation, ethnicity and migration: the comparison of Finland, Hungary and Russia. Working papers on population, family and welfare, No. 7. Budapest: Hungarian Central Statistical Office, Demographic Research Institute. 64 pp.

Melegh, Attila, Elena Kondratieva, Perttu Salmenhaara, Annika Forsander, László Hablicsek, and Adrienn Hegyesi. 2005. Globalisation, ethnicity and international migration: the comparison of Finland, Hungary and Russia. Demográfia 48:123-67.

Moisala, Jutta. 2004. Maahanmuutto ja sen taloudelliset vaikutukset [Immigration and its economic effects]. Raportteja, No. 4. Helsinki: Palkansaajien tutkimuslaitos. 66 pp. ISBN 952-209-003-4.

Munter, Arja. 2005. Pääkaupunkiseudun maahanmuuttajat tilastoissa [The immigrants in the Helsinki Metropolitan Area in statistics]. Pp. 11-23 in Maahanmuuttajien elinolot pääkaupunkiseudulla, edited by Tuula Joronen. Helsinki: Helsingin kaupungin tietokeskus.

Nieminen, Mauri. 2004. Ulkomaalaistaustaisen väestön määrä lisääntyy [The number of population with foreign background is on the increase]. Stat.fi (3):10-11.

Nieminen, Mauri. 2005. Ulkomaalaisten määrä kasvussa Suomessa [The number of foreigners is on the increase in Finland]. Pp. 175-80 in Kymmenvuosikatsaus 2005: teemana yritystoiminta. Helsinki: Tilastokeskus.

Nieminen, Mauri. 2006. Maahanmuutto korvaa työvoimavajetta [Immigration compensates labor shortage]. Tieto \& Trendit (8):52-4. 
Nieminen, Mauri. 2006. Väestökehitys on maahanmuuttajien varassa [Population development is based on immigration]. Tieto \& Trendit (6-7):61-3.

Paananen, Seppo. 2005. Maahanmuuttajien integrointi: vaikea ja ristiriitainen hanke [The integration of immigrants: a difficult and controversial effort]. Pp. 17380 in Maahanmuuttajien elämää Suomessa, edited by Seppo Paananen. Helsinki: Tilastokeskus.

Pakarinen, Mikko. 2004. Monikulttuurisuus ja tietoyhteiskunta [Multiculturalism and information society]. Sitran raportteja, No. 36. Helsinki: Sitra. 154 pp. ISBN 951-374154-0. Accessed on Jan. 11, 2008. Available online at http://www.sitra.fi/julkaisut/raportti36.pdf?download=Lataa + pdf

Pehkonen, Aini. 2006. Maahanmuuttajan kotikunta [Home municipality of the immigrant]. Helsinki: Kunnallisalan kehittämissäätiö. Kunnallisalan kehittämissäätiön tutkimusjulkaisut, No. 52. 91 pp ISBN 952-5514-35-8. Accessed on Jan. 29, 2008. Available online at http://www.polemiikki.fi/files/1120-Tutkimusjulk_52_net.pdf

Perhoniemi, Riku, and Inga Jasinskaja-Lahti. 2006. Maahanmuuttajien kotoutuminen pääkaupunkiseudulla: seurantatutkimus vuosilta 1997-2004 [Integration of immigrants in the capital area: follow-up survey in 1997-2004]. Tutkimuksia, No. 2, 2006. Helsinki: Helsingin kaupungin tietokeskus. 122, [1] pp. ISBN 952-473-673-X.

Saarela, Jan. 2006. Muuttoliiketutkimuksessa otetaan kansainvälisiä edistysaskeleita [International progress is made in migration research]. Hyvinvointikatsaus(3):51-6.

Rekonen, Petri. 2006. Etelä-Pohjanmaan väestö ja siirtolaisuus Ruotsiin 1940-1960 [The population of Southern Ostrobothnia and migration to Sweden 1940-1960]. Pp. 179-91 in Etelä-Pohjanmaan historia, Vol. 7. Seinäjoki: Etelä-Pohjanmaan liitto.

Salminen, Heikki. 2006. Lapset sodankäynnin uhreina: sotalapset ja lastensiirrot 1900-luvulla [Children as victims of war: wartime children and child evacuations in the 20th century]. Historiallinen aikakauskirja 104(2):132-41.

Seppälä, Antti. 2004. Muukalainen ja virkavalta: ulkomaalaishallinto Suomessa vuosina 1973-2003 [The alien and the authorities: immigrant administration in Finland in 1973-2003]. Helsinki: Työministeriö. 205, [1] pp. ISBN 951-735-895-4.

Skog, Irene. 2005. Venäjän Kaukoitä tyhjenee [The Far East of Russia is becoming empty]. Tietoaika (7):8-10.

Snellman, Hanna. 2005. Göteborg som "den största byn i Salla kommun": utflyttningen från norra Finland till södra Sverige [Gothenburg as "the largest village in the municipality of Salla": migration from Northern Finland to Southern Sweden]. Pp. 107-19 in Lokala perspektiv på 1960-talet: bilen, fritiden och den ökande rörligheten [Local perspectives in the 1960s: the car, free time, and the increasing mobility], edited by Marjatta Rahikainen. Studier i stads- och kommunhistoria, No. 28. Stockholm: Stadsoch kommunhistoriska institutet. 
Söderling, Ismo. 2004. Finland in Sweden's footsteps: differences and similarities in immigration and integration policies. $\mathrm{Pp} .42-51$ in Power and control: perspectives on integration and multiculturalism in Europe, edited by Kimi Kärki. Publications of the Population Research Institute, Series D 43 \& Publications of the Doctoral Program of Cultural Interaction and Integration, No. 8. [Helsinki]: The Family Federation of Finland, The Population Research Institute \& Turku: The Graduate School on Cultural Interaction and Integration and the Baltic Sea Region.

Söderling, Ismo. 2004. Ruotsin opetukset maahanmuutosta [Sweden's lessons of immigration]. Ulkopolitiikka (1):41-46.

Söderling, Ismo. 2005. Suomen väestökysymys ja maahanmuutto [The Finnish population issue and immigration]. Pp. 13-23 in Olemme muuttaneet: näkökulmia maahanmuuttoon, perheiden kotoutumiseen ja ammatillisen työn käytäntöihin, edited by Anne Alitolppa-Niitamo, Ismo Söderling, and Stina Fågel. Helsinki: Väestöliitto, Väestöntutkimuslaitos \& [Väestöliiton] Kotipuu.

Tanner, Arno. 2004. Työvoiman maahanmuutto on globaali kysymys: paluusta ja rahalähetyksistä kehitysmaahan [Immigration is a global issue: about return and remittances to developing country. Siirtolaisuus $=$ Migration 31(3):4-11.

Tanner, Arno. 2004. Työvoiman maahanmuutto ja globaali etiikka: paluusta ja rahalähetyksistä kehitysmaahan [Immigration of labor and global ethics: about return and remittances to a developing country]. Yhteiskuntapolitiikka 69(1):54-60.

Tanner, Arno. 2005. Emigration, brain drain and development: the case of Sub-Saharan Africa. Helsinki: East-West Books \& Migration Policy Institute. 183 pp. ISBN 952-99592-1-4.

Tanner, Arno. 2005. Suomen maahan- ja maastamuutto murroksessa: miten on tultu tähän päivään ja mitkä ovat eväät huomiselle? [Finnish immigration and emigration at turning-point: what has been the development until today and what are the resources for tomorrow?]. Siirtolaisuus = Migration 32(4):12-8.

Tanner, Arno. 2005. Limitations to win-win-win in global labor migration: acute emigration, migrant return and money remittances in developing country development. Yearbook of Population Research in Finland 41:97-116.

Tanner, Arno. 2006. The future of international migration governance: a survey of subject priorities in a new organizational model. Helsinki: East-West Books. 173 pp. ISBN 952-99592-0-6.

Tanni, Katri. 2004. Staattisuutta ja muutoksen tuulia: Australian siirtolaisuuspolitiikka ja maailmankuvan muutos toisen maailmansodan jälkeen [Static situation and winds of change: Australia's migration policy and change of the conception of the world after the Second World War]. Siirtolaisuus = Migration 31(3):31-4.

Valtonen, Kathleen. 2004. Transnationalism and its significance to the Vietnamese community in Finland. Pp. 223-36 in New challenges for the welfare society, edited by Vesa Puuronen, Antti Häkkinen, Anu Pylkkänen, Tom Sandlund, and Riikka Toivanen. Publications of Karelian Institute, No. 142. Joensuu: University of Joensuu. 
Virkamäki, Suvi. 2005. "Att få ett gott hem..." Finska krigsbarnsadoptioner i Stockholm 1946-1947 [To have a good home: Finnish adopted children in Stockholm in 19461947]. Web Reports, No. 7. Accessed on Oct. 19, 2007. Turku: Siirtolaisuusinstituutti. Available online at http://www.migrationinstitute.fi/pdf/webreports7.pdf

\section{Internal migration}

Ahlgren-Leinvuo, Hanna. 2005. Pakolaiset Suomen kunnissa - kuntapaikasta pääkaupunkiseudulle [Refugees in Finnish municipalities - from municipalities to the Helsinki metropolitan area]. Pp. 25-45 in Maahanmuuttajien elinolot pääkaupunkiseudulla, edited by Tuula Joronen. Helsinki: Helsingin kaupungin tietokeskus.

Ainsaar, Mare. 2004. Reasons for move: a study on trends and reasons of internal migration with particular interest in Estonia 1989-2000. Turun yliopiston julkaisuja, Sarja B, Humaniora, Part 274. Turku: University of Turku. 222 pp. ISBN 951-292658-X. Doctoral dissertation.

Hakamies, Pekka (ed.). 2005. Moving in the USSR: western anomalies and northern wilderness. Studia Fennica, Historica, No. 10. Helsinki: Finnish Literature Society. 161 pp. ISBN 951-746-695-1.

Heikkilä, Elli and Sari Korkalainen. 2004. Aluekehitys ja muuttoliike työssäkäyntialueiden näkökulmasta [Regional development and migration in the point of view of employment areas]. Siirtolaisuus $=$ Migration 31(2):40-3.

Heikkilä, Elli. 2006. Muuttoliike ja työmarkkinoiden dynamiikka [Migration and the dynamics of the labor market]. Pp. 98-111 in Muuttaako Onni maalle? Suurten ikäluokkien valinta: Muuttoliikesymposium 2005, Turku 23.-24.11, edited by Elli Heikkilä. Siirtolaisuustutkimuksia, No. A 28. Turku: Siirtolaisuusinstituutti.

Hunnakko, Pekka. 2006. Suurten ikäluokkien eläkeläisten maallemuuttopotentiaali [The potential of the pensioners of the baby boom cohorts to move to the countryside]. Pp. 112-26 in Muuttaako Onni maalle? Suurten ikäluokkien valinta: Muuttoliikesymposium 2005, Turku 23.-24.11, edited by Elli Heikkilä. Siirtolaisuustutkimuksia, No. A 28. Turku: Siirtolaisuusinstituutti.

Itäpuisto, Timo. 2006. Koti Hankasalmen Kymppi Kyliin: muuttonäkymiä Jyväskylän kupeesta [Moving to Hankasalmi's Kymppi villages: mobility outlooks from the neighborhood of Jyväskylä]. Pp. 69-85 in Muuttaako Onni maalle? Suurten ikäluokkien valinta: Muuttoliikesymposium 2005, Turku 23.-24.11, edited by Elli Heikkilä. Siirtolaisuustutkimuksia, No. A 28. Turku: Siirtolaisuusinstituutti.

Kahila, Petri and Katja Rinne-Koski. 2006. Joustavan elämäntavan paikka ja tila kaupungin ja maaseudun vuorovaikutuksessa [The place and space of flexible way of life in the interaction of town and countryside]. Pp. 173-84 in Muuttaako Onni maalle? Suurten ikäluokkien valinta: Muuttoliikesymposium 2005, Turku 23.-24.11, edited by Elli Heikkilä. Siirtolaisuustutkimuksia, No. A 28. Turku: Siirtolaisuusinstituutti.

Kokko, Karoliina. 2004. Maahanmuuttajien Suomen sisäinen muuttoliike: mikä vetää Turkuun muualta Suomesta? [Immigrants' internal migration in Finland: Turku's pull factors]. Siirtolaisuus $=$ Migration 31(3):22-30. Sum. in Eng. 
Kotiranta, Mikko. 2004. Satakunnan muuttoliiketutkimus 2004 [The migration study of Satakunta in 2004]. Satakunnan TE-keskuksen julkaisusarja, No. 4/2004. Pori: Satakunnan TE-keskus. 85 pp. ISBN 952-5537-05-6. Accessed on Feb. 4, 2008. Available online at http://www.te-keskus.fi/Public/download.aspx?ID=4180\&GUID $=\{\mathrm{DE} 3005 \mathrm{~F} 0-4 \mathrm{~B} 63-4050-\mathrm{B} 27 \mathrm{~A}-\mathrm{D} 04 \mathrm{~F} 30 \mathrm{D} 17095\}$

Kotiranta, Mikko. 2005. Satakunnan muuttoliike 2000-luvun alussa: kuntatalouden näkökulma [Migration in Satakunta in the beginning of the 2000s: the viewpoint of local government finance]. Satakunnan TE-keskuksen julkaisusarja, No. 1/2005. Pori: Satakunnan TE-keskus. 124 pp. Accessed on Jan. 31, 2008. Available online at http://www.te-keskus.fi/Public/download.aspx?ID $=4182 \&$ GUID $=\{$ DB77044B-AF7A4C28-90F4-EF52A1CFA62D

Kumpulainen, Mikko. 2006. Maailmalle menetetty vai korkoa kasvanut? Koulutetut munttajat maaseudun kannalta [Lost to the world or accrued interest? Educated migrants in point of view of the countryside]. Karjalan tutkimuslaitoksen raportteja, No. 1, 2006. Joensuu: Karjalan tutkimuslaitos. 134 pp. ISBN 952-458-828-5.

Kupiszewski, Marek, Elli Heikkilä, Mauri Nieminen, Helen Durham, Philip Rees, and Dorota Kupiszewska. 2005. Internal migration and regional population dynamics in 1980s and 1990s Finland. Siirtolaisuus = Migration 32(3):2-5.

Kytö, Hannu and Leena Aatola. 2006. Muuttuva maallemuuttaja: maallemuuttajien elämäntavat ja maallemuuton mukanaan tuomat muutokset [Changing rural migrants: The ways of life of rural migrants and the changes caused by the moving to the countryside]. Julkaisuja, No. 3:2006. 105, [32] pp. Helsinki: Kuluttajatutkimuskeskus. ISBN 951-698-139-9. Sum. in Swe and Eng.

Laakso, Seppo, Timo Halme, Päivi Kilpeläinen, Heikki A. Loikkanen, and Mari Vaattovaara. 2005. Kirkkonummen kunnan muuttoliiketutkimus [Migration study of the Kirkkonummi municipality]. Helsingin yliopiston maantieteen laitoksen julkaisuja, B, No. 52. Helsinki: Helsingin yliopisto. 80, [1] pp. ISBN 952-10-2836-X. Accessed on Jan. 31, 2008. Available online at http://www.helsinki.fi/geography/Kirkkonummi raportti_2005.pdf

Lonkila, Markku and Anna-Maria Salmi. 2005. The Russian work collective and migration. Europe-Asia Studies 57(5):681-703.

Mattila, Johanna. 2004. Seniorimuutto maaseudulle [Migration of senior citizens to rural areas]. Siirtolaisuus 31(4):18-23:22-30.

Myrskylä, Pekka. 2004. Muuttoliikkeen vaikutukset pienenevät ja leviävät [The effects of migration decrease and spread]. Tietoaika (9):16-18.

Myrskylä, Pekka. 2004. Työn ja asumisen eriytyminen jatkuu [The differentiation of work and residence continues]. Hyvinvointikatsaus (3):32-7.

Nieminen, Mauri. 2006. Maassamuuton uudet kuviot [New patterns of internal migration]. Pp. 28-37 in Muuttaako Onni maalle? Suurten ikäluokkien valinta: Muuttoliikesymposium 2005, Turku 23.-24.11., edited by Elli Heikkilä. Siirtolaisuustutkimuksia, No. A 28. Turku: Siirtolaisuusinstituutti. 
Ovaska, Esko. 2004. Migration, small municipalities and the transition in the forms of social capital. Siirtolaisuus $=$ Migration 31(2):15-22.

Pehkonen, Aini. 2004. Kylä kutsuu...: tutkimus tulomuuttoprosesseista maaseudulle [A village calls...: a study on inmigration processes to rural areas]. Siirtolaisuustutkimuksia A. 26. Turku: Siirtolaisuusinstituutti. 179 pp. ISBN 951-9266-80-1. Sum in Fin, Eng. Doctoral dissertation.

Pehkonen, Aini. 2006. Miten paluu- ja tulomuuttoprosessit onnistuvat maaseudulle? [How return and inmigration processes succeed to rural areas?]. Pp. 49-68 in Muuttaako Onni maalle? Suurten ikäluokkien valinta: Muuttoliikesymposium 2005, Turku 23.-24.11, edited by Elli Heikkilä. Siirtolaisuustutkimuksia, No. A 28. Turku: Siirtolaisuusinstituutti.

Pirkanmaan liitto [The Council of Tampere Region]. 2005. Pirkanmaan muuttoliike ja muuttajat [Migration and migrants in Pirkanmaa]. Sarja B, No. 94.Tampere: Pirkanmaan liitto. 70 pp. ISBN 951-590-205-3.

Rapo, Markus. 2006. Väestö suuntaa kehyskuntiin [People move to municipalities near large cities]. Tieto \& Trendit (8):30-2.

Rekonen, Petri. 2006. Siirtokarjalaiset Etelä-Pohjanmaalla [Karelian evacuees in Southern Ostrobothnia]. Pp. 193-200 in Etelä-Pohjanmaan historia. Vol. 7. Seinäjoki: Etelä-Pohjanmaan liitto

Volk, Raija. 2005. Hyvinvointi ja muuttoliike [Welfare and migration]. Maaseudun uusi aika 13(2):79-86.

Volk, Raija. 2006. Uraputki Helsingissä vai rauhallinen maalaisasuminen? [Career in Helsinki or peaceful life in the countryside?]. Pp. 130-9 in Muuttaako Onni maalle? Suurten ikäluokkien valinta: Muuttoliikesymposium 2005, Turku 23.-24.11, edited by Elli Heikkilä. Turku: Siirtolaisuusinstituutti.

Yousfi, Saara. 2005. Kahdenuranperheet työmarkkinoilla ja aluedynamiikassa [Dual career families in local labour markets and in regional dynamics]. Siirtolaisuustutkimuksia, A, No. 27. Turku: Siirtolaisuusinstituutti. 183 pp. ISBN 951-9266-83-6. Sum. in Eng. Doctoral dissertation.

\section{HISTORICAL DEMOGRAPHY AND DEMOGRAPHIC HISTORY}

Aikio, Aslak. 2004. Marriage among the Saame of the Kemi region of Lapland in 17501900. Pp. 39-66 in Family life on the Northwestern margins of imperial Russia, edited by Tapio Hämynen, Jukka Partanen, and Yury Shikalov. Studia Carelica Humanistica, No. 19. Joensuu: Joensuu University Faculty of Humanities.

Bladh, Gabriel and Christer Kuvaja (ed.). 2006. Kahden puolen Pohjanlahtea: Ihmisiä, yhteisöjä ja aatteita Ruotsissa ja Suomessa 1500-luvulta 1900-luvulle [At both sides of the Gulf of Bothnia: people, communities, and ideas in Sweden and Finland from the 1500s to the 1990s]. Vol. 1. Historiallinen arkisto No. 123:1. Helsinki: Suomalaisen Kirjallisuuden Seura. 555 pp. ISBN 951-746-825-3. 
Bladh, Gabriel and Maud Wedin. 2006. "Erämaasta torppia raivaamaan" : metsäsuomalaisten muuttoliike Ruotsiin ja heidän siellä harjoittamansa asutustoiminta 1500- ja 1600-luvuilla [From wilderness to building crofts: migration of the forest Finns to Sweden and their settlement there in the 16th and 17th centuries]. Pp. 51-107 in Kahden puolen Pohjanlahtea: ihmisiä, yhteisöjä ja aatteita Ruotsissa ja Suomessa 1500-luvulta 1900-luvulle, edited by Gabriel Bladh and Christer Kuvaja. Historiallinen arkisto, No. 123:1. Helsinki: Suomalaisen Kirjallisuuden Seura.

Engman, Max. 2005. Suureen itään: suomalaiset Venäjällä ja Aasiassa [To the great East: Finns in Russia and Asia]. Suomen siirtolaisuuden historia, No. 5. Turku: Siirtolaisuusinstituutti. 512 pp. ISBN 951-92766-84-4.

Engman, Max and Jan Samuelson. 2006. Valtakunnan hajoaminen ja muuttoliike: maantieteellinen liikkuvuus Suomesta ja Suomeen ennen vuotta 1809 ja sen jälkeen [The dissolution of the kingdom and migration: geographic mobility from Finland and to Finland before 1809 and afterwards]. Pp. 259-325 in Kahden puolen Pohjanlahtea: ihmisiä, yhteisöjä ja aatteita Ruotsissa ja Suomessa 1500-luvulta 1900-luvulle, edited by Gabriel Bladh and Christer Kuvaja. Historiallinen arkisto, No. 123:1. Helsinki: Suomalaisen Kirjallisuuden Seura.

Hiltunen, Juha. 2006. Metsäintiaani ja suomalainen: lännen valloitus hieman erilaisesta perspektiivistä [Forest Indian and the Finn: the conquest of the West from a different perspective]. Siirtolaisuus $=$ Migration 33(1):24-9.

Hämynen, Tapio. 2004. History of the Karelian orthodox families in Suojärvi, 15001939. Pp. 93-133 in Family life in Northwestern margins of imperial Russia, edited by Tapio Hämynen, Jukka Partanen, and Yury Shikalov. Studia Carelica Humanistica, No. 19. Joensuu: Joensuu University Faculty of Humanities.

Keskinen, Jouni, Jarmo Peltola, and Sami Suodenjoki. 2005. Tamperelaiset: tehdaskaupungin väestö, alue ja asuminen 1918-1940 [The population of Tampere: the population, area, and housing of the industrial city in 1918-1940]. Tampereen museoiden julkaisuja, No. 79. Tampere: Tampereen museot. 307, [5] pp. ISBN 951-609-245-4.

Kuhanen, Jan. 2005. Poverty, health and reproduction in early colonial Uganda. Joensuun yliopiston julkaisuja. [38]. Joensuu: Joensuun yliopisto. 434 pp. ISBN 952458-630-4. Doctoral dissertation. Accessed on Nov. 21, 2007. Available online at http://joypub.joensuu.fi/publications/dissertations/kuhanen_poverty/kuhanen.pdf

Laasonen, Pentti. 2005. Novgorodin imu: miksi ortodoksit muuttivat Käkisalmen läänistä Venäjälle 1600-luvulla? [Pull of Novgorod: the reasons for the Orthodox migration from Käkisalmi province to Russia in the $17^{\text {th }}$ century]. Historiallisia tutkimuksia, No. 222. Helsinki: Suomalaisen Kirjallisuuden Seura. 171 pp. ISBN 951-746-697-8.

Leitzinger, Antero. 2006. Suomen tataarit: vuosina 1868-1944 muodostuneen muslimiyhteisön menestystarina [Finnish tatars: the success story of a Muslim community formed in 1868-1944]. Helsinki: East-West Books. 279, [1] pp. ISBN 952-99592-2-2.

Linnanmäki, Eila. 2005. Espanjantauti Suomessa: influenssapandemia 1918-1920 [The Spanish influenza of 1918-1920 in Finland]. Bibliotheca historica, No. 95. Helsinki: Suomalaisen Kirjallisuuden Seura. 242 pp ISBN 951-746-716-8. Doctoral dissertation. 
Lähteenmäki, Maria. 2004. Kalotin kansaa: rajankäynnit ja vuorovaikutus Pohjoiskalotilla 1809-89 [People of the Arctic Area of the Nordic Countries: marking the borders and the interplay at the Arctic Areas]. Historiallisia tutkimuksia, No. 220. Helsinki: Suomalaisen Kirjallisuuden Seura. 519, [1] pp. ISBN 951-746-599-8.

Lähteenmäki, Maria. 2005. The white man's burden? Settlers in Finnish Lapland in the nineteenth century. Pp. 70-82 in The North Calotte: perspectives on the histories and cultures of northernmost Europe, edited by Maria Lähteenmäki and Päivi Maria Pihlaja. Publications of the Department of History, University of Helsinki. Inari: Puntsi.

Meskus, Mianna. 2005. To exclude or to enclose? Medicalization of abortion in Finland, 1900-1950. Scandinavian Journal of History 30(1):45-60.

Moring, Beatrice. 2004. Together or apart; sibling inequality, marriage and household strategies in pre-industrial Finland. Pp. 93-173 in Family life on the Northwestern margins of imperial Russia, edited by Tapio Hämynen, Jukka Partanen, and Yury Shikalov. Studia Carelica Humanistica, No. 19. Joensuu: Joensuu University Faculty of Humanities.

Partanen, Jukka. 2004. Isän tuvasta omaan tupaan: Väestö ja kotitaloudet Karjalankannaksen maaseudulla 1750-1870 [From father's cottage to one's own cottage: population and households in rural areas of the Karelian isthmus 1750-1870]. Bibliotheca Historica, No. 86. Helsinki: Suomalaisen Kirjallisuuden Seura. 208 pp. ISBN 951-746-621-8. Doctoral dissertation. Sum. in Eng.

Partanen, Jukka. 2004. Marriage behaviour in the Käkisalmi region of the Karelian isthmus, 1760-1860. Pp. 147-73 in Family life on the Northwestern margins of imperial Russia, edited by Tapio Hämynen, Jukka Partanen, and Yury Shikalov. Studia Carelica Humanistica, No. 19. Joensuu: Joensuu University Faculty of Humanities.

Polla, Matti. 2004. The family systems among Eastern Karelians and ethnic Russians in the 19th century. Pp. 201-38 in Family life on the Northwestern margins of imperial Russia, edited by Tapio Hämynen, Jukka Partanen, and Yury Shikalov. Studia Carelica Humanistica, No. 19. Joensuu: Joensuu University Faculty of Humanities.

Polla, Matti. 2005. Vuokkiniemen perhejärjestelmä 1800-luvulla - tilastollinen luonnehdinta [The family system of Vuokkiniemi in the $1800 \mathrm{~s}$ - a statistical characterization]. Historiallinen aikakauskirja 103(1):71-84.

Polla, Matti and Marina Kuropjatnik. 2004. Household arrangements among the Saami of Akkala, Northern Russia, in the 19th century. Pp. 239-60 in Family life on the Nortwestern margins of imperial Russia, edited by Tapio Hämynen, Jukka Partanen, and Yury Shikalov. Studia Carelica Humanistica, No. 19. Joensuu: Joensuu University Faculty of Humanities.

Rekonen, Petri. 2006. Etelä-Pohjanmaan valtameren takainen siirtolaisuus 1860-1940 [The overseas migration of Southern Ostrobothnia 1860-1940]. Pp. 121-78 in EteläPohjanmaan historia, Vol. 7. Seinäjoki: Etelä-Pohjanmaan liitto.

Roms, Jussi. 2005. Ruotsalaiset vuorimiehet rakentamassa "Pietarin Falunia" Pitkärantaan 1879-1904 [Swedish miners building "St. Petersburg's Falun" in Pitkäranta in 1879-1904]. Siirtolaisuus $=$ Migration 32(2):20-4. 
Satokangas, Reija. 2004. Talonpoika ja teollisuus vastakkain ja rinnakkain - Kemijokisuun agraariyhteistön murros 1860-1938 [Peasant farmers and industry at the same Kemijoki river mouth]. Studia Historica Septentrionalia, No. 44. Rovaniemi: Pohjois-Suomen Historiallinen Yhdistys. 495 pp. ISBN 952-9888-23-6. Doctoral dissertation.

Waris, Elina. 2004. The family and marriage in Southern Estonia. Pp. 333-58 in Family life on the Northwestern margins of imperial Russia, edited by Tapio Hämynen, Jukka Partanen, and Yury Shikalov. Studia Carelica Humanistica, No. 19. Joensuu: Joensuu University Faculty of Humanities.

Warpula, Kirsi. 2006. Perhe, suku ja elämänkaari [Family and life course]. Pp. 108215 in Suomalaisen arjen historia, edited by Kai Häggman, Markku Kuisma, Pirjo Markkola, and Panu Pulma. Vol. 1. Espoo: Weilin+Göös.

Westerlund, Lars (ed.). 2004. Sotaoloissa vuosina 1914-22 surmansa saaneet [Victims of war between 1914 and 1922: statistical report]. Valtioneuvoston kanslian julkaisusarja, No. 10/2004.Helsinki: Valtioneuvoston kanslia. 269 pp. ISBN 952-5354-52-0. Accessed on Dec. 5, 2007. Available online at http://www.vnk.fi/julkaisukansio/2004/ j10-sotaoloissa-1914-22-surmansa-saaneet/pdf/fi.pdf

Virtanen, Arto. 2004. Ehkäisystä keisarinleikkauksiin: antiikin gynekologiaa [From contraception to cesareans; gynecology of the antiquity]. Pp. 251-67 in Antiikin lääketieteen perintö, edited by Andreo Larsen. Helsinki: Yliopistopaino.

Vuorinen, Heikki S. 2006. Tautinen Suomi 1857-1865 [Diseases in Finland in 18571865]. Tampere: Tampere University Press. 220 pp. ISBN 951-44-6495-8.

Xaviera, Torres Joerges. 2005. Importancia de la viruela, gastroenteritis aguda y paludismo en Finlandia entre 1749 y 1850 [On the importance of smallpox, acute gastroenteritis and malaria in Finland between 1749 and 1850]. Acta Universitatis Ouluensis. B. Humaniora, No. 68. Oulu: University of Oulu. 489 pp+CD-ROM ISBN. 951-42-7940-9. Accessed on Dec. 4, 2007.Available online at

http://herkules.oulu.fi/isbn9514279417/isbn9514279417.pdf. Sum. in Fin. and Eng. Doctoral dissertation.

\section{J. CHARACTERISTICS}

Björklund, Krister. 2006. Patching the population pyramid in Japan - an ethnic dilemma. Siirtolaisuus $=$ Migration 33(4):29-36.

Blomgren, Jenni. 2005. Huono-osaisuus Suomen kaupunkiseutukunnissa: alue-erot ja sosiaalisen ympäristön vaikutukset 1990-luvulla [Social exclusion in Finnish urban regions: area differences and effects of the social environment in the 1990's]. Helsingin yliopiston sosiologian laitoksen tutkimuksia, No. 246. Helsinki: Helsingin yliopisto. 288, [20] pp. ISBN 952-10-2556-5. Accessed on March 7. 2008. Available online at https://oa.doria.fi/bitstream/handle/10024/3406/huonoosa.pdf?sequence=2 . Doctoral dissertation. Sum. in Eng. 
Blomgren, Jenni. 2006. Asuinseutujen vaikutukset aikuisväestön huono-osaisuusriskeihin [Effects of the regions of residence on risks of social exclusion among working-age adults]. Yhteiskuntapolitiikka 71(1):92-5.

Elomaa, Hanna. 2004. The Swedish-speaking educated classes in Finland: losing power, gaining identity? Pp. 52-70 in Power and control: perspectives on integration and multicultarism in Europe, edited by Kimi Kärki. Publications of the Population Research Institute, Series D 43/2004 \& Publications of the Doctoral Program of Cultural Interaction and Integration, No. 8. Helsinki: The Family Federation of Finland, The Population Research Institute \& Turku: University of Turku, The Graduate School on Cultural Interaction and Integration in the Baltic Sea Region.

Huju, Päivi. 2005. Suomen väestö ikääntyy - mikä on tilanne kilpailijamaissa? [Finland's population is aging - what is the situation in Finland's competitor countries?]. Pp. 197-9 in Kymmenvuosikatsaus 2005: teemana yritystoiminta, edited by Jaakko Autio. Helsinki: Tilastokeskus.

Huovari, Janne and Raija Volk. 2004. Ikääntyminen ja maaseudun työmarkkinat [Aging and labour market in rural areas]. Pellervon taloudellisen tutkimuslaitoksen raportteja, No. 190. Helsinki: Pellervon taloudellinen tutkimuslaitos. 88, [5] pp. ISBN 952-5299-77-5. Accessed on Feb. 4, 2008. Available online at http://www.ptt.fi/dokumentit/rap190_26060614.pdf

Karisto, Antti (ed.). 2005. Suuret ikäluokat [The baby boomers]. Tampere: Vastapaino. 365 pp. ISBN 951-768-171-2.

Karisto, Antti. 2005. Suuret ikäluokat kuvastimessa [Baby boomers in the mirror]. Pp. 17-58 in Suuret ikäluokat, edited by Antti Karisto. Tampere: Vastapaino.

Kautto, Mikko (ed.). 2004. Ikääntyminen voimavarana: tulevaisuusselonteon liiteraportti 5 [Aging as a resource: appendix 5 to the Government report on the future]. Valtioneuvoston kanslian julkaisusarja, No. 33/2004. Helsinki: Valtioneuvoston kanslia. 202 pp. ISBN 952-5354-75-X. Accessed on March 7, 2008. Available online at http://www.vnk.fi/julkaisukansio/2004/j33-ikaantyminen-voimavarana/pdf/fi.pdf

Ketola, Tanja and Jan Kunz. 2005. Population ageing and its consequences in Finland: a review of current trends and debates. Research reports, Series B, No. 21. Tampere: University of Tampere, Department of Social Policy and Social Work. 80 pp. ISBN 951-44-6154-1.

Kirmo, Outi. 2005. Tampereen venäläinen väestö vuosina 1918-1950: etninen identiteetti ja sosiaaliset suhteet [The Russian population in Tampere 1918-1950: ethnic identity and social relations]. Pp. 342-65 in Vieraat kulkijat - tutut talot: näkulmia etnisyyden ja köyhyyden historiaan Suomessa, edited by Antti Häkkinen, Panu Pulma, and Miika Tervonen. Historiallinen arkisto, No. 120. Helsinki: Suomalaisen Kirjallisuuden Seura.

Martikainen, P., N. Mäki, A. Karisto, and O. Rahkonen. 2004. Pääkaupunkiseudun suuriin ikäluokkiin kuuluvien ylempien toimihenkilöiden sosiaalinen ja maantieteellinen tausta [Social and geographic origins of baby boomers in upper white-collar occupations in the Helsinki area]. Yhteiskuntapolitiikka 69(1):31-38. 
Martikainen, Tuomas. 2005. Maahanmuuttajat, uskonto ja Suomi [Immigrants, religion, and Finland]. Siirtolaisuus $=$ Migration 32(1):19-27.

Martikainen, Tuomas, Seppo Sintonen, and Pirkko Pitkänen. 2006. Ylirajainen liikkuvuus ja etniset vähemmistöt [Transnational migration and ethnic minorities]. Pp. 9-41 in Ylirajainen kulttuuri: etnisyys Suomessa 2000-luvulla, edited by Tuomas Martikainen. Tietolipas, No. 212. Helsinki: Suomalaisen Kirjallisuuden Seura.

Myrskylä, Pekka (ed.). 2005. Tallella ikä eletty...: ikääntyminen tilastoissa [Aging in statistics]. Elinolot, 2005. Helsinki: Statistics Finland. 194 pp. ISBN 952-467-436-X.

Myrskylä, Pekka. 2005. Tallella ikä eletty...: ikääntyminen tilastoissa [Aging in statistics]. Pp. 15-33 in Tallella ikä eletty...: ikääntyminen tilastoissa. Elinolot, 2005. Helsinki: Statistics Finland.

Nieminen, Mauri. 2006. Vähenevä ja ikääntyvä väestö tulevaisuuden haaste [Decreasing and aging population is a future challenge]. Kuntapuntari(3):9-11.

Nihtilä, E. and P. Martikainen. 2004. Ikäihmisten yksinasuminen Suomessa vuosina 1970-2000 [Trends in living alone among the elderly in Finland in 1970-2000]. Yhteiskuntapolitiikka 69(2):135-46.

Oilinki-Nenonen, Pirkko. 2004. Ikääntymisen ennakointi: ikärakenteen muutos ja sen keskeiset vaikutukset Pohjois-Pohjanmaalla [Predicting aging: change in age structure and its central impacts]. Pohjois-Pohjanmaan TE-keskuksen julkaisuja, No. 17. Oulu: Pohjois-Pohjanmaan TE-keskus. 46 pp. ISBN 952-5547-05-1.

Penttilä, Irmeli. 2005. Lapsen syntymä muuttaa asumista [The birth of a child changes housing conditions]. Pp. 43-61 in Perheiden muuttuvat elinolot, edited by Henna Isoniemi and Irmeli Penttilä. Research Reports, No. 243. Helsinki: Statistics Finland.

Piekkola, Hannu. 2004. Demographic aspects of ageing and time use in a set of European countries. Keskusteluaiheita, No. 899. Helsinki: ETLA. 20, [5] pp. Accessed on Feb.18, 2008. Available online at http://www.etla.fi/files/1005 dp899.pdf

Pukkila, Tarmo. 2005. Ikävallankumous [Age revolution]. Kunnallisalan kehittämissäätiön Polemia-sarja, No. 57. Helsinki: Kunnallisalan kehittämissäätiö. 95 pp. ISBN 952-5514-20-X. Accessed on Feb. 18, 2008. Available online at http://www.polemiikki.fi/files/1146-Polemia57_netti.pdf

Räsänen, Antti. 2005. Religiousness of Finnish immigrants in Belgium. Siirtolaisuus = Migration 32(3):7-18.

Saarela, Jan. 2004. De förmögna finlandssvenskarna? [The wealthy Swedish speakers in Finland?]. Janus 12(1):80-96. Sum. in Eng.

Simpura, Jussi. 2005. Mitä tilastot voivat kertoa ikääntymisestä? [What statistics can tell about aging?]. Pp. 7-13 in Tallella ikä eletty...:ikääntyminen tilastoissa. 2005. Helsinki: Statistics Finland. 
Sisäasiainministeriö [Ministry of the Interior]. 2005. Väestön ikääntymiseen varautuminen sisäasiainministeriön hallinnonalalla [Preparing for the aging of population in the administrative sector of the Ministry of the Interior] Sisäasianministeriön julkaisu, No. 36, 2005. Helsinki: Sisäasiainministeriö. 60 pp. ISBN 951-734-912-2. Accessed on Jan. 31, 2007. Available online at

http://www.intermin.fi/intermin/biblio.nsf/A6A0E9CC21BA7EA6C22570CE002B0049/ \$file/362005.pdf

Vuori, Pekka. 2004. Ikääntyvät helsinkiläiset [Aging population in Helsinki]. Pp. 919 in Eläkeikäisten elinolot Helsingissä. Tilastoja, No. 21, 2004. Helsinki: Helsingin kaupungin tietokeskus.

\section{K. DEMOGRAPHIC AND ECONOMIC INTERRELATIONS AND NATURAL RESOURCES}

Akhlaq, Ahmad. 2005. Getting a job in Finland: the social networks of immigrants from the Indian subcontinent in the Helsinki Metropolitan labour market. Research reports, No. 247. Helsinki: University of Helsinki. 154 pp. ISBN 952-10-2791-6. Accessed on March 7, 2008. Available online at https:/oa.doria.fi/bitstream/handle/10024/3415/gettinga.pdf?sequence $=1$. Doctoral dissertation.

Akhlaq, Ahmad. 2006. Maahanmuuttajien tukeutuminen sosiaalisiin verkostoihin työllistymisessä = beroende av sociala nätverk bland invandrare på väg in på arbetsmarknaden [Social networks and the employment of immigrants]. Kvartti(3):23-31.

Blomberg-Kroll, Helena. 2004. Integration through work in a multicultural society? A study on elite groups' debate on immigrants and the labour market in two Nordic welfare states. Pp. 237-54 in New challenges for the welfare society, edited by Vesa Puuronen, Antti Häkkinen, Anu Pylkkänen, Tom Sandlund, and Riikka Toivanen. Publications of Karelian Institute, No. 142. Joensuu: University of Joensuu.

Forsander, Annika. 2004. Social capital in the context of immigration and diversity: economic participation in the Nordic welfare states. Journal of International Migration and Integration 5(2):207-27.

Forsander, Annika and Mika Raunio. 2005. Globalisoituvat työmarkkinat: asiantuntijamaahanmuuttajat [Globalizing labor market: immigrating specialists in Finland]. Pp. 26-53 in Kulttuurien välinen työ, edited by Pirkko Pitkänen. Helsinki: Edita.

Hakovirta, Mia. 2006. Yksinhuoltajaäitien työllisyys, toimeentulo ja työmarkkinavalinnat [Employment, income, and labour market choices of lone mothers]. Väestöntutkimuslaitoksen julkaisusarja D, No. 45/2006. Helsinki: Väestöliitto. 203 pp. ISBN 951-9450-51-3. Doctoral dissertation. Sum. in Swe and Eng.

Heikkilä, Elli, Taru Järvinen, Jörg Neubauer, and Lars Olof Persson. 2004. Labour market integration in the Baltic Sea Region: before and after EU enlargement. Accessed online on Oct. 19, 2007. Web Reports, No. 3. Turku: Institute of Migration \& Nordregio. 35 pp. Available at http://www.migrationinstitute.fi/pdf/webreports3.pdf 
Heikkilä, Elli and Maria Pikkarainen. 2006. Maahanmuuttajien työllisyys [The employment of immigrants]. Pp. 257-77 in Ylirajainen kulttuuri: etnisyys Suomessa 2000luvulla, edited by Tuomas Martikainen. Tietolipas, No. 212. Helsinki: Suomalaisen Kirjallisuuden Seura.

Huovari, Janne, Jaakko Kiander, and Raija Volk. 2006. Väestörakenteen muutos, tuottavuus ja kasvu [Changes in population structure, productivity, and growth]. Pellervon taloudellisen tutkimuslaitoksen raportteja, No. 198. Helsinki: Pellervon taloudellinen tutkimuslaitos. 130, [5] pp. Accessed on Feb. 17, 2008. Available online at http://www.ptt.fi/dokumentit/rap198 07080613.pdf

Hytti, Helka. 2004. Early exit from the labour market through the unemployment pathway in Finland. European Societies 6(3):265-97.

Hytti, Helka. 2006. Why are Swedes sick but Finns unemployed? International Journal of Social Welfare 15(2):131-41.

Hämäläinen, Kari, Aki Kangasharju, Sari Pekkala, and Matti Sarvimäki. 2005. Maahanmuuttajien vero-tulonsiirtoaste [The rate of transfer of the tax revenue paid by immigrants]. Siirtolaisuus $=$ Migration 32(2):3-11.

Hätälä, Johanna and Ville Koskimäki. 2005. Maahanmuuttajat Oulun työmarkkinoilla [Immigrants in Oulu's labor market]. Pp. 55-66 in Kansainvälistyvä Oulu - monikulttuurinen Oulu?, edited by Jussi S. Jauhianen and Katri Suorsa. Nordia Tiedonantoja, No. 1/2005. Oulu: Pohjois-Suomen maantieteellinen seura \& Oulun yliopiston maantieteellinen seura.

Joronen, Tuula. 2005. Työ on kahden kauppa - maahanmuuttajien työmarkkina-aseman ongelmia [Work is a deal of two parties - the labor force status problems of the immigrants]. Pp. 59-82 in Maahanmuuttajien elämää Suomessa, edited by Seppo Paananen. Helsinki: Tilastokeskus.

Joronen, Tuula. 2005. Maahanmuuttajat yrittäjinä [Immigrants as entreprenours]. Pp. 161-87 in Työväestön rajat, edited by Matti Hannikainen. Väki voimakas, No. 18. Helsinki: Työväen historian ja perinteen tutkimuksen seura.

Kallio, Olavi. 2005. Väestönmuutosten vaikutukset kuntatalouteen: Tilastokeskuksen ennusteisiin perustuvien väestömuutosten 2004-2010 ja 2010-2020 vaikutukset Pirkanmaan kuntien talouteen [The effects of population change on municipalities' economy: the effects of the population changes 2004-2010 and 2010-2020 based on the projections of Statistics Finland on Pirkanmaa's municipalities' economy]. Sarja D, No. 81. Tampere: Pirkanmaan liitto. 43, [2] pp. ISBN 951-590-196-0.

Kannisto, Jari. 2004. Työeläkkeelle lähdetään vähän alle 59-vuotiaina [People leave on employment pension slightly under 59 years old]. Kuntapuntari (2):13-5.

Kautto, Mikko and Pekka Sinko (ed.). 2004. Talouskasvu ja julkistalous ikääntyneen väestön oloissa: tulevaisuusselonteon liiteraportti 4 [Economic growth and public economy in aging society: Appendix 4 of the Government report on the future]. Valtioneuvoston kanslian julkaisusarja, No. 32/2004. Helsinki: Valtioneuvoston kanslia. 
208 pp. ISBN 952-5354-74-1. Accessed on March 3, 2008. Available online at http://www.vnk.fi/julkaisukansio/2004/j32-talouskasvu-ja-julkistalous/pdf/fi.pdf

Kyhä, Henna. 2006. Miksi lääkäri ei kelpaa lääkäriksi? Korkeakoulutetut maahanmuuttajat vaikeasti työllistyvä ryhmä [Why a doctor cannot be a doctor? The highly educated immigrants have difficulties to get work]. Siirtolaisuus $=$ Migration 33(3):1-9.

Kyhä, Henna. 2006. Korkeakoulutetut maahanmuuttajat Suomen työmarkkinoilla [Immigrants with university degree in the Finnish labor market]. Aikuiskasvatus 26(2):122-9.

Lehmijoki, Ulla. 2004. Väestöllinen siirtymä ja taloudellinen kasvu [Demographic transition and economic growth]. Kansantaloudellinen aikakauskirja 100(2):166-72.

Lankinen, Markku. 2005. Muuttoliikkeen vaikutus Helsingin väestörakenteeseen ja veropohjaan [The effect of migration on the population structure and tax revenue of Helsinki]. Tutkimuksia, No. 4, 2005. Helsinki: Helsingin kaupungin tietokeskus. 118 pp. ISBN 952-473-512-1. Sum in Fin, Swe, and Eng.

Laurila, Hannu. 2006. Three approaches to the economics of inter-municipal migration. Acta Universitatis Tamperensis, No. 1174. Tampere: Tampere University Press. 195 pp. ISBN 951-44-6722-1. Accessed on Jan. 29, 2008. Available online at http://acta.uta.fi/pdf/951-44-6723-X.pdf

Markkanen, Kirsi, and Soile Tammisto. 2005. Maahanmuuttajat hoitoalan työyhteisöissä: Tehyn selvitys monikulttuurisuudesta [Immigrants at the workplace in the health care sector: Tehy survey on multiculturalism]. Tehyn julkaisusarja, B, Selvityksiä, No. 3, 2005. Helsinki: Tehy. 64 pp. ISBN 951-9172-43-2. Accessed on Jan. 29, 2008. Available online at http://tehy-fi-bin.directo.fi/@,Bin/d154254f248d9f792618dbec448 f04ff/1201623721/application/pdf/1568284/Maahanmuutto.PDF. Sum. in Fin., Swe, and Eng. The survey is available also in English.

Myrskylä, Pekka. 2004. Vanhimman ikäryhmän työllisyysasteessa jopa 50 prosenttiyksikön erot kunnittain [The employment rate of the oldest age group has even differences of 50 percentage points by municipality]. Kuntapuntari(2):3-6.

Myrskylä, Pekka. 2005. Työvoimamuutokset [Change in labor force]. Pp. 51-87 in Tallella ikä eletty...: ikääntyminen tilastoissa. Elinolot, 2005. Helsinki: Statistics Finland.

Myrskylä, Pekka. 2006. Ikääntyvien työllisyys kasvaa nopeasti [The employment of the aged is growing fast]. Kuntapuntari(3):3-8.

Myrskylä, Pekka. 2006. Muuttoliike ja työmarkkinat [Migration and the labor market]. Työpoliittinen tutkimus, No. 321. Helsinki: Työministeriö. 148, [3] pp. ISBN 952-490-033-5. Accessed on Jan. 31, 2008. Available online at

http://www.mol.fi/mol/fi/99 pdf/fi/06 tyoministerio/06 julkaisut/06 tutkimus/tpt321.pdf

Ollikainen, Virve. 2006. Gender differences in transitions from unemployment: micro evidence form Finland. Labour 20(1):159-98. 
Parkkinen, Pekka. 2004. Economic growth rate may be high in spite of a decreasing working-age population in Finland. Yearbook of Population Research in Finland 40:105-17.

Pehkonen, Aini. 2006. Immigrants' paths to employment in Finland. Finnish Yearbook of Population Research 42(2006):113-28.

Pehkonen, Aini. 2006. Maahanmuuttajien työllistyminen Suomessa [The employment of immigrants in Finland]. Siirtolaisuus = Migration 33(1):1-10.

Puhakka, Mikko. 2005. The effects of aging population on the sustainability of fiscal policy. Bank of Finland Research Discussion Papers, No. 26/2005. Helsinki: Bank of Finland. 26 pp. ISBN 952-462-251-3. Accessed on Feb. 18, 2008. Available online at http://www.suomenpankki.fi/NR/rdonlyres/BE409877-A906-40C7-93F5B6F1CFD155FD/0/0526netti.pdf

Reuter, Anni, Magdalena Jaakkola, and Simo Mannila. 2005. Maahanmuuttajien resurssit Suomen työmarkkinoilla [The resources of immigrants in the Finnish labor market]. Kuntoutus 28(2):7-22.

Saarela, Jan. 2006. Wealth in two ethnic groups: the role of internal migration background. Finnish Yearbook of Population Research 42(2006):43-64.

Saarela, Jan and Fjalar Finnäs. 2006. Can the low unemployment rate of Swedish speakers in Finland be attributed to structural factors? The Journal of Socio-Economics 35(3):498-513.

Salin, Milla. 2005. Äitien työssäkäynti lapsen saannin jälkeen [The employment of mothers after childbirth]. Pp. 87-108 in Perheiden muuttuvat:elinolot: artikkeleita lapsiperheiden elämänmuutoksista, edited by Henna Isoniemi and Irmeli Penttilä. Tutkimuksia, No. 243. Helsinki: Statistics Finland.

Sjöblom-Immala, Heli. 2006. Maahanmuuttajat Turussa yrittäjinä ja palkansaajina [Immigrants as entreprenours and wage earners in Turku]. Työpoliittinen tutkimus, No. 318. Helsinki: Työministeriö. 103, [2] pp. ISBN 952-490-028-9. Accessed on Jan. 30, 2008.

http://www.mol.fi/mol/fi/99 pdf/fi/06 tyoministerio/06 julkaisut/06 tutkimus/tpt318.pdf. Sum. in Fin., Swe., and in Eng.

Sutela, Hanna. 2005. Maahanmuuttajat palkkatyössä [Immigrants in labor force]. Pp. 83-109 in Maahanmuuttajien elämää Suomessa, edited by Seppo Paananen. Helsinki: Tilastokeskus.

Wahlbeck, Östen. 2005. Turkkilaiset maahanmuuttajat yrittäjinä Suomessa: paikallinen ja transnationaali sosiaalinen pääoma [Turkish immigrants as entrepreneurs in Finland: local and transnational social capital]. Janus 13(1):39-53.

Virtanen, Petri, Marja-Liisa Niinikoski, Risto Karinen, and Maarit Paananen. 2004. Maahanmuuttajista tärkeä osa pirkanmaalaista työvoimaa? [Immigrants are becoming an important part of Pirkanmaa labor force?]. Pirkanmaan TE-keskuksen julkaisuja, 
No. 7. Tampere: Pirkanmaan työvoima- ja elinkeinokeskus. 61 pp. ISBN 952-558612-X. Accessed on Feb. 18, 2008. Available online at https://www.pirkanmaanennakointipalvelu.info/micaj storage/ 21F58B9E8DF77FC7D097EAADC0F0249C/4948/te-keskus julkaisu 7 mamu.pdf

Volk, Raija. 2004. Maaseudulla riittää työvoimaa [There is enough labor force in the rural areas]. Kuntapuntari(3):10-3.

Vähätalo, Kari. 2005. Maahanmuuttajat ja kantaväestö pitkäaikaistyöttöminä pääkaupunkiseudulla [Immigrants and Finnish population as long-term unemployed in the Helsinki metropolitan area]. Tutkimuksia, No. 2, 2005. Helsinki: Helsingin kaupungin tietokeskus. 142 pp. ISBN 952-473-438-9.

\section{DEMOGRAPHIC AND NONECONOMIC INTERRELATIONS}

Bartley, M., P. Martikainen, M. Shipley, and M. Marmot. 2004. Gender differences in the relationship of partner's social class to behavioural risk factors and social support in the Whitehall II study. Social Science \& Medicine 59(9):1925-36.

Chandola, T., P. Martikainen, M. Bartley, E. Lahelma, M. Marmot, S. Michikazu, A. Nasermoaddeli, and S. Kagamimori. 2004. Does conflict between home and work explain the effect of multiple roles on mental health? A comparative study of Finland, Japan, and the UK. Journal of Epidemiology 33(4):884-93.

Clarke, Kris. 2006. HIV/AIDS as a transnational health care issue: migrants in the European Union. Siirtolaisuus = Migration 33(1):11-6.

Dal, Espen, Johan Fritzell, Eero Lahelma, Pekka Martikainen, Anton Kunst, and Johan P. Mackenbach. 2006. Welfare state regimes and health inequalities in Social inequalities in health: new evidence and policy implications, edited by Johannes Siegrist and Michael Marmot. Oxford: Oxford University Press.

Dykes, J., E. Brunner, P. Martikainen, and J. Wardle. 2004. The socioeconomic gradient in body size and obesity among women: the role of dietary restraint, disinhibition and hunger in the Whitehall II study. International Journal of Obesity 28(2):262-68.

Fedorova, Natalia, Katja Kesseli, Elina Haavio-Mannila, and the REFER group. 2005. Reproductive health and sexuality in St. Petersburg: report of a survey of young men in 2003. Working papers, Department of Sociology, University of Helsinki, No. 61. Helsinki: University of Helsinki \& STAKES National Research and Development Centre. 80, [2] pp. ISBN 952-10-2505-0.

Haavio-Mannila, Elina and Osmo Kontula. 2006. Seksuaalielämää Pietarissa [Sex life in St. Petersburg]. Pp. 289-318 in Katse Venäjään: suomalaisen Venäjä-tutkimuksen antologia, edited by Jouko nikula. Aleksanteri-sarja, No. 3:2006. Helsinki: Aleksanteri-instituutti.

Harkonmäki, Karoliina, Eero Lahelma, Pekka Martikainen, Ossi Rahkonen, and Karri Silventoinen. 2006. Mental health functioning (SF-36) and intentions to retire early 
among ageing municipal employees: the Helsinki Health Study. Scandinavian Journal of Public Health 34(2):190-8.

Hassi, Juhani and Mika Rytkönen. 2005. Climate warming and health adaptation in Finland. Finnish Environment Institute Mimeogaphs, No. 337. Helsinki: Finnish Environment Institute. 22, [2] pp. ISBN .952-11-2110-6. Accessed on Dec. 7, 2007. Available online at http://www.ymparisto.fi/download.asp?contentid=45326\&lan=en

Heikkinen, Eino. 2005. Iäkkäiden ihmisten terveys ja toimintakyky [The health and performance of the aged]. Pp. 327-35 in Suomalaisten terveys, edited by Arpo Aromaa, Jussi Huttunen, Seppo Koskinen, and Juha Teperi. Helsinki: Duodecim \& KTL \& STAKES.

Helasoja, Ville, Eero Lahelma, Ritva Prättälä, Anu Kasmel, Jurate Klumbiene, and Iveta Pudule. 2006. The socioeconomic patterning of health in Estonia, Latvia, Lithuania and Finland. European Journal of Public Health 16(1):8-20.

Helasoja, Ville, Eero Lahelma, Ritva Prättälä, Jurate Klumbiene, Iveta Pudule, and Mare Tekkel. 2006. Trends in the magnitude of educational inequalities in health in Estonia, Latvia, Lithuania and Finland during 1994-2004. Public Health 120(9):841-53.

Huoponen, Kirsi, Tuuli Lappalainen, and Marja-Liisa Savontaus. 2006. Idästä vai lännestä? Suomalaisten geneettiset sukujuuret [From East or West? The genetic ancestry of the Finns]. Duodecim 122(1):63-8.

Jasinskaja-Lahti, Inga, Karmela Liebkind, and Riku Perhoniemi. 2006. Perceived discrimination and well-being: a victim study of different immigrant groups. Journal of Community \& Applied Social Psychology 16(4):267-84.

Joutsenniemi, Kaisla E., Tuija P. Martelin, Seppo V. Koskinen, Pekka T. Martikainen, Tommi T. Härkänen, Riitta M. Luoto, and Arpo J. Aromaa. 2006. Official marital status, cohabiting, and self-rated health - time trends in Finland, 1978-2001. European Journal of Public Health 16(5):476-83.

Joutsenniemi, Kaisla, Tuija Martelin, Pekka Martikainen, Sami Pirkola, and Seppo Koskinen. 2006. Living arrangements and mental health in Finland. Journal of Epidemiology and Community Health 60(6):468-75.

Juonala, Markus, Jorma S.A. Viikari, and Olli T. Raitakari. 2006. Miksi sepelvaltimotauti on edelleen enemmän itä- ja kuin länsisuomalaisten vaiva? [Why coronary heart disease is still more a problem in Eastern than Western Finland?]. Duodecim 122(1):55-61.

Kontula, Osmo. 2004. Bi- and homosexuality in the national surveys in Europe. Pp. 21123 in Same-sex couples, same-sex partnerships, and homosexual marriages: a focus on cross-national differentials, edited by Marie Digoix and Patric Festy. Documents du travail. 124. Paris: INED Institut national d'études démographiques.

Kontula, Osmo. 2006. Seksuaalelu algus Eestis Euroopa kontekstis [Starting sex life in Estonia in the European context]. Pp. 39-55 in Seksuaalsus Eestis: Ajalugu, Tänäpäev, edited by Olev Poolamets, Elina Haavio-Mannila, Osmo Kontula, and Kai Haldre. Tallinn: Eesti Akadeemiline Seksoloogia Selts. 
Kontula, Osmo and Olev Poolamets. 2006. Seksuaaltervis ja sellega seonduvad õigused ning suundumused [Sexual health and related sexual rights and their trends in Estonia]. Pp. 321-42 in Seksuaalsus Eesti: Ajalugu, Tänäpäev, Arengud, edited by Olev Poolamets, Elina Haavio-Mannila, Osmo Kontula, and Kai Haldre. Tallinn: Eesti Akadeemiline Seksoloogia Selts.

Koponen, Päivikki and Arpo Aromaa. 2005. Suomalaisten terveys kansainvälisessä vertailussa [The health of Finns in international comparison]. Pp. 277-97 in Suomalaisten terveys, edited by Arpo Aromaa, Jussi Huttunen, Seppo Koskinen, and Juha Teperi. Helsinki: Duodecim \& KTL \& STAKES.

Kosunen, Elise. 2004. Seksuaalikäyttäytymisen muutokset [Changes in sexual behavior]. Pp. 46-60. Sum. in Eng. in Näkökulmia nuorten seksuaaliterveyteen, edited by Elise Kosunen and Maija Ritamo Raportteja, No. 282. Helsinki: STAKES Sosiaali- ja terveysalan tutkimus- ja kehittämiskeskus.

Laaksonen, Mikko, Sirpa Sarlio-Lähteenkorva, Päivi Leino-Arjas, Pekka Martikainen, and Eero Lahelma. 2005. Body weight and health status: importance of socioeconomic position and working conditions. Obesity Research 13:2169-77.

Laaksonen, M., O. Rahkonen, P. Martikainen, and E. Lahelma. 2005. Multiple dimensions of socioeconomic position and self-rated health: the contribution of childhood socioeconomic circumstances, adult socioeconomic status and material resources. American Journal of Public Health 95:1403-09.

Laaksonen, M., E. Roos, O. Rahkonen, P. Martikainen, and E. Lahelma. 2005. Influence of material and behavioural factors on occupational class differences in health. Journal of Epidemiology and Community Health 59(2):163-69.

Laaksonen, Mikko, Ossi Rahkonen, Pekka Martikainen, and Eero Lahelma. 2006. Associations of psychosocial working conditions with self-rated general health and mental health among municipal employees. International Archives of Occupational and Environmental Health 79(3):205-12.

Laes, Esko. 2005. Synnyttäjien terveys [Health of the parturients]. Pp. 321-26 in Suomalaisten terveys, edited by Arpo Aromaa, Jussi Huttunen, Seppo Koskinen, and Juha Teperi. Helsinki: Duodecim \& KTL \& STAKES.

Lahelma, Eero. 2004. Nainen yhteiskunnassa ja työelämässä: nykynaiseen kohdistuvat odotukset; työ, perhe, terveys ja elintavat [Women in society and working life: the expectations set on women in contemporary society: work, family, health, and way of life]. Pp. 25-9 in Vaihdevuosien hormonihoito. Helsinki: Suomalainen Lääkäriseura Duodecim.

Lahelma, Eero, Pekka Martikainen, Ossi Rahkonen, Eva Roos, and Peppiina Saastamoinen. 2004. Henkilöstön terveydentilan vaihtelu ammattiaseman mukaan: Helsinki Health Studyn tuloksia [Variations in health by occupational class among employees: results from the Helsinki Health Study]. Sosiaalilääketieteellinen aikakauslehti 41(2):95-107. Sum. in Eng. 
Lahelma, E., P. Martikainen, O. Rahkonen, and E. Roos. 2005. Occupational class inequalities across key domains of health: results from the Helsinki Health Study. European Journal of Public Health 15(5):504-10.

Lahelma, Eero, Mikko Laaksonen, Pekka Martikainen, and Ossi Rahkonen. 2006. Multiple measures of socioeconomic circumstances and common mental disorders. Social Science \& Medicine 63(5):1383-99.

Liinamo, Arja. 2005. Suomalaisnuorten seksuaalikasvatus ja seksuaaliterveystiedot oppilaan ja koulun näkökulmasta: arviointia terveyden edistämisen viitekehyksessä [Sexual education and sexual health knowledge among Finnish adolescents at pupil and school level - evaluation from the point of view of health promotion]. Jyväskylä studies in sport, physical education and health, No. 106. Jyväskylä: Jyväskylän yliopisto. 111, [69] pp. ISBN 951-39-2138-7. Accessed on Nov. 30, 2007. Available at http://dissertations.jyu.fi/studsport/951392176X.pdf. Doctoral dissertation. Sum. in Eng.

Mackenbach, J.P., P. Martikainen, C.W.N. Looman, J.A. Dalstra, A.E. Kunst, E. Lahelma, and SEdHA working group. 2004. The shape of the relationship between income and self-assessed health: an international study. International Journal of Epidemiology 34(2):286-93.

Manderbacka, Kristiina. 2005. Koettu terveys ja tiedossa oleva sairastavuus [Experienced health and known morbidity]. Pp. 130-33 in Suomalaisten terveys, edited by Arpo Aromaa, Jussi Huttunen, Seppo Koskinen, and Juha Teperi. Helsinki: Duodecim \& KTL \& STAKES.

Martelin, Tuija, Seppo Koskinen, and Eero Lahelma. 2005. Väestöryhmien väliset terveyserot [Health differences between population groups]. Pp. 266-76 in Suomalaisten terveys, edited by Arpo Aromaa, Jussi Huttunen, Seppo Koskinen, and Juha Teperi. Helsinki: Duodecim \& KTL \& STAKES.

Martikainen, Pekka, Netta Mäki, Antti Karisto, and Ossi Rahkonen. 2004. Pääkaupunkiseudun suuriin ikäluokkiin kuuluvien ylempien toimihenkilöiden sosiaalinen ja maantieteellinen tausta [Social and geographic origins of baby boomers in upper white-collar occupations in the Helsinki area]. Yhteiskuntapolitiikka 69(1):31-38. Sum. in Eng.

Martikainen, P., E. Lahelma, M. Marmot, M. Sekine, N. Nishi, and S. Kagamimori. 2004. A comparison of socioeconomic differences in physical functioning and perceived health among male and female employees in Britain, Finland and Japan. Social Science \& Medicine 59:1287-95.

Morikawa, Y., P. Martikainen, J. Head, M. Marmot, M. Ishizaki, and H. Nakagawa. 2004. A comparison of socio-economic differences in long-term sickness absence in a Japanese cohort and a British cohort of employed men. European Journal of Public Health 14(4):413-16.

Nikander, Eivor (ed.). 2004. Kvinnohälsa på Åland [Health of women in Åland]. Åländsk utredningsserie, No. 3, 2004. Mariehamn: Ålands landskapsregering, social- och miljöavdelningen. 53, [1] pp.Accessed online on Dec. 3, 2007. Available online at http://www.regeringen.ax/.composer/upload/modules/publikationer/kvinnohalsa pa land.pdf 
Näyhä, Simo and Mauri Laakso (ed.). 2005. Lapin terveyskatsaus [Health report on Lapland]. Kansanterveystiede, Tutkimus, No. 3/2005. Oulu: Oulun yliopisto, kansanterveystieteen ja yleislääketieteen laitos. $161 \mathrm{pp}$. ISBN 951-42-7641-8.

Palosuo, Hannele. 2004. Self-rated health in Moscow and Helsinki. Pp. 44-64 in Constructions of Health and Illness: European perspectives, edited by Ian Shaw and Kaisa Kauppinen. Aldershot, England: Ashgate.

Palosuo, Hannele and Seppo Koskinen. 2005. Terveyserot ja niiden kaventaminen Suomessa [Health differences and narrowing them in Finland]. Terveydenhoitaja (8):12-17.

Palosuo, Hannele, Eila Linnanmäki, Marita Sihto, and Seppo Koskinen. 2006. Sosioekonomiset terveyserot - terveyspolitiikan ikuisuusongelma? [Socioeconomic differences in health - the eternal problem in health policy?]. Duodecim 122(12):1409-11.

Palosuo, Hannele, Marita Sihto, Ilmo Keskimäki, Seppo Koskinen, Eero Lahelma, Kristiina Manderbacka, Ritva Prättälä, and Eila Linnanmäki. 2005. Monet maat etsivät keinoja terveyserojen kaventamiseen: Englannin, Hollannin ja Ruotsin kokemukset kiinnostavat [Many countries seek means to decrease the differences in health: the experiences of England, The Netherlands, and Sweden are of interest]. Dialogi 15(5):18-21. Accessed on Dec. 4, 2007. Available online at http://dialogi.stakes.fi/FI/arkisto/2001-2005/2001-05.htm

Palosuo, Hannele, Marita Sihto, Seppo Koskinen, Eero Lahelma, Ritva Prättälä, Ilmo Keskimäki, and Kristiina Manderbacka. 2006. Sosioekonomiset terveyserot ja terveyspolitiikka Suomessa, Ruotsissa, Englannissa ja Hollannissa [Socioeconomic health differences and health policy in Finland, Sweden, England and the Netherlands]. Yhteiskuntapolitiikka 71(2):154-66.

Penttilä, Irmeli. 2005. Terveydentila ja sairastavuus [Health condition and morbidity]. Pp. 113-30 in Tallella ikä eletty...: ikääntyminen tilastoissa. Elinolot, 2005. Helsinki: Statistics Finland.

Poolamets, Olev, Elina Haavio-Mannila, Osmo Kontula, and Kai Haldre (ed.). 2006. Seksuaalsus Eestis: ajalugu, tänäpäev, arengud [Sexuality in Estonia: history, today, progress]. Tallinn: Eesti Akadeemiline Seksoloogia Selts. 360 pp. ISBN 9949-13-356-4.

Rahkonen, O., S. Arber, E. Lahelma, P. Martikainen, and K. Silventoinen. 2004. Understanding income equalities in health among men and women in Britain and Finland. Pp. 335-54 in Embodying inequality: epidemiologic perspectives, edited by N. Krieger. Amityville, NY: Baywood Publishing Company, Inc.

Rahkonen, Ossi, Mikko Laaksonen, Pekka Martikainen, Eva Roos, and Eero Lahelma. 2006. Job control, job demands, or social class? The impact of working conditions on the relation between social class and health. Journal of Epidemiology and Community Health 60:50-4.

Rajantie, Jukka and Antti Perheentupa. 2005. Lasten terveys [Health of children]. Pp. 299-306 in Suomalaisten terveys, edited by Arpo Aromaa, Jussi Huttunen, Seppo Koskinen, and Juha Teperi. Helsinki: Duodecim \& KTL \& STAKES. 
Rautio, Mikko. 2004. Väestön ikääntymisen yhteys rikollisuuden kehitykseen Suomessa vuosina 2003-2030 [The relation of aging to the development of criminality in Finland in 2003-2030]. Sisäasiainministeriön julkaisu, No. 50/2004. Helsinki: Sisäasiainministeriö. 85 pp. ISBN 951-734-786-3. Accessed on Feb. 18, 2008. Available online at http://www.intermin.fi/intermin/biblio.nsf/61349242C9B5C929C2256F5100493258/ $\$$ file/502004.pdf

Rimpelä, Arja. 2005. Nuorten terveys [The health of young people]. Pp. 307-16 in Suomalaisten terveys, edited by Arpo Aromaa, Jussi Huttunen, Seppo Koskinen, and Juha Teperi. Helsinki: Duodecim \& KTL \& STAKES.

Roos, E., E. Lahelma, P. Saastamoinen, and J.I. Elstad. 2005. The association of employment status and family status with health among women and men in four Nordic countries. Scandinavian Journal of Public Health 33(4):250-60.

Roos, Eva, Bo Burström, Peppiina Saastamoinen, and Eero Lahelma. 2005. A comparative study of the patterning of women's health by family status and employment status in Finland and Sweden. Social Science \& Medicine 60(11):2443-51.

Saarela, Jan and Fjalar Finnäs. 2005. Geographical extraction and the Finnish-Swedish health differential in Finland. Yearbook of Population Research in Finland 41:61-73.

Sahi, Timo. 2005. Varusmiesten terveys [Health of conscripts]. Pp. 317-20 in Suomalaisten terveys, edited by Arpo Aromaa, Jussi Huttunen, Seppo Koskinen, and Juha Teperi. Helsinki: Duodecim \& KTL \& STAKES.

Shemeikka, R. and P. Alkio. 2004. HIV/aidsin ehkäiseminen Afrikan suurimpia haasteita [HIV/AIDS prevention is one the major challenges of Africa]. Väestöviesti(3):6-8.

Shemeikka, Riikka and Paula Alkio. 2004. Aids Afrikassa: tietopaketti HIV/aids-tilanteesta [AIDS in Africa]. Väestötietosarja, No. 12. Helsinki: Väestöliitto. 32 pp. ISBN 951-9450-03-3.

Sipilä, Petteri and Pekka Martikainen. 2005. Fyysisen ja psyykkisen terveyden väliset alue-erot ja niiden taustat pääkaupunkiseudulla [Geographical variations of physical and mental health and their determinants in the Helsinki metropolitan area]. Sosiaalilääketieteellinen aikauslehti 42(3):202-18.

Stafford, M., P. Martikainen, E. Lahelma, and M. Marmot. 2004. Neighbourhoods and self-rated health: a comparison on London and Helsinki. Journal of Epidemiology and Community Health 58(9):772-78.

Tolonen, Hanna, Satu Helakorpi, Kirsi Talala, Ville Helasoja, Tuija Martelin, and Ritva Prättälä. 2006. 25-year trends and socio-demographic differences in response rates: Finnish adult health behaviour survey. European Journal of Epidemiology 21(6):409-15.

Winter, Torsten, Eva Roos, Ossi Rahkonen, Pekka Martikainen, and Eero Lahelma. 2006. Work-family conflicts and self-rated health among middle-aged municipal employees in Finland. International Journal of Behavioral Medicine 13(4):276-85. 
Virtanen, Pekka, Antti Saloniemi, Jussi Vahtera, Mika Kivimäki, Marianna Virtanen, and Markku Koskenvuo. 2006. The working conditions and health of non-permanent employees: are there differences between private and public labour markets? Economic and Industrial Democracy 27(1):39-65.

\section{POLICIES}

Anttonen, Anneli and Jorma Sipilä. 2004. Jäikö hyvinvointivaltio historiaan [Is the welfare society history]. Tiede (7):44-47.

Anttonen, Anneli and Liina Sointu. 2006. Hoivapolitiikka muutoksessa: julkinen vastuu pienten lasten ja ikääntyneiden hoivasta 12:ssa Euroopan maassa: hyvinvointivaltion rajat -hanke [Changing caring policy: public responsiblity for the care of small children and the aged in 12 European countries: The Limits of the Welfare State-Project]. Helsinki: STAKES. 136 pp. ISBN 951-33-1905-9. Accessed on Dec. 28, 2007. Available online at http://www.stakes.fi/verkkojulkaisut/raportit/M232-VERKKO.pdf

Einasto, Heili. 2004. The politics of maternity: from conception to lactation. Pp. 11835 in Power and control: perspectives on integration and multiculturalism in Europe, edited by Kimi Kärki. Publications of the Population Research Institute, Series D 43/2004 \& Publications of the Doctoral Program of Cultural Interaction and Integration, No. 8. Helsinki: The Family Federation of Finland, The Population Research Institute \& Turku: University of Turku, The Graduate School on Cultural Interaction and Integration and the Baltic Sea Region.

Einasto, Heili. 2005. To be or not to be a mother: policies on abortion in twentienthcentury Estonia. Pp. 47-69 in Paikat sekaisin - localities in turmoil: näkökulmia paikallisuuden muutoksiin = perspectives on the reshaping of locality, edited by Maija Mäkikalli. Kulttuurisen vuorovaikutuksen ja integraation tutkijakoulun julkaisuja, No. 9. Turku: Kulttuurisen vuorovaikutuksen ja integraation tutkijakoulu.

Etelä-Suomen lääninhallitus [State Provincial Office of Southern Finland]. 2006. Etelä-Suomen läänin perhepoliittinen ohjelma 2006-2015 [The family policy program 2006-2015 of the province of Southern Finland]. Etelä-Suomen lääninhallituksen julkaisuja, No. 113. Helsinki: Etelä-Suomen lääninhallitus. 27 pp. ISBN 952-460-163-X. Accessed on Dec. 28, 2007. Available online at http://www.laaninhallitus.fi/lh/biblio. nsf/4FB506969DF93339C22572600048F8BA/\$file/113.pdf

Forssén, Katja, Anita Haataja, and Mia Hakovirta. 2005. Policy changes, employment, and single parenthood in Finland. Yearbook of Population Research in Finland 41:29-45.

Haataja, Anita. 2004. Pohjoismaiset vanhempainvapaat kahden lasta hoitavan vanhemman tukena [Nordic parental leaves supporting the parents taking care of a child]. Janus 12(1):25-48.

Haataja, Anita. 2005. Outcomes of the two 1990s family policy reforms at the turn of the 2000s in Finland. Yearbook of Population Research in Finland 41:5-27.

Haataja, Anita. 2006. Pohjoismainen ansaitsija-hoivaajamalli: Ruotsin ja Suomen perhevapaajärjestelmän vertailu [Nordic breadwinner-caretaker models: a comparison of Finland and Sweden]. Helsinki: Sosiaali- ja terveysministeriö. 100, [2] pp. ISBN 
952-00-2109-4. Accessed on Dec. 28, 2007. Available at http://www.stm.fi/Resource.phx/publishing/store/2006/08/hu1154515038978/passthru. pdf. Sum. in Swe, Eng.

Helén, Ilpo and Katja Yesilova. 2006. Shepherding desire: sexual health promotion in Finland from the 1940s to the 1990s. Acta Sociologica 49(3):257-72.

Hellsten, Sirkku K. 2006. Beyond Europe: rhetoric of reproductive rights in global population policies. Pp. 199-241 in Women's reproductive rights, edited by Heather Widdows, Itziar Alkorta Idiakez, and Aitziber Emaldi Cirión. New York, NY: Palgrave Macmillan.

Hiilamo, Heikki. 2004. Changing family policy in Sweden and Finland during the 1990s. Social Policy and Administration 38(1):21-40.

Hiilamo, Heikki. 2004. Changing family policy in Sweden and Finland during the 1990s. Pp. 123-144 in Welfare in Finland, edited by Matti Heikkilä and Mikko Kautto. Helsinki: STAKES National Research and Development Centre for Welfare and Health.

Hiilamo, Heikki. 2006. Akantappolaista isäkiintiöön: perhepolitiikan pitkä linja Suomessa ja Ruotsissa [From "wife-killing law" to fathers' quota: the trajectories of family policy in Finland and Sweden]. Helsinki: STAKES Sosiaali- ja terveysalan tutkimus- ja kehittämiskeskus. 169 pp. ISBN 951-33-1843-5.

Hiilamo, Heikki and Olli Kangas. 2006. Trap for women or freedom to choose? Political frames in the making of child home care allowance in Finland and Sweden. Publications of the Department of Social Policy, A, No. 18. Turku: University of Turku. 40 pp. ISBN 951-29-3182-6.

Jokisaari, Selene. 2006. Kotouttamislain merkitys kotoutumisessa maahanmuuttajan näkökulmasta [The importance of integration law in integration from the immigrant's point of view]. Web Reports, No. 18. Turku: Siirtolaisuusinstituutti. 220 pp. Accessed on Feb. 21, 2008. Availaible online at http://www.migrationinstitute.fi/pdf/webreports18.pdf

Kari, Matti. 2006. Suomen EU-jäsenyys ja perheturva [The EU-membership of Finland and social security for families]. Pp. 25-41 in Lapsi ja perhe Euroopan unionissa, edited by Tero Kallio and Ulla Ojala. Helsinki: Lastensuojelun Keskusliitto.

Kautto, Mikko (ed.). 2004. Väestökehitykseen vaikuttaminen - tulisiko syntyvyyttä ja maahanmuuttoa lisätä? Tulevaisuusselonteon liiteraportti 3 [Influencing population development - should fertility and immigration be increased? Appendix 3 of the Government report on the future ]. Valtioneuvoston kanslian julkaisusarja, No. 31/2004. Helsinki: Valtioneuvoston kanslia. 135 pp. ISBN 952-5354-73-3. Accessed on March 3, 2008. Available online at

http://www.vnk.fi/julkaisukansio/2004/j31-vaestokehitykseen-vaikuttaminen_pdf/fi.pdf

Kautto, Mikko (ed.). 2004. Alueellinen väestökehitys ja politiikan uudistamistarpeet: tulevaisuusselonteon liiteraportti 2 [Regional population development and needs for renewing policy: Appendix 2 of the Government report on the future]. Valtioneuvoston kanslian julkaisusarja, No. 30/2004. Helsinki: Valtioneuvoston kanslia. 119 pp. ISBN 952-5354-72-5. Accessed on March 3, 2008. Available online at http://www.vnk.fi/julkaisukansio/2004/j30-alueellinen-vaestokehitys/pdf/134312.pdf 
Kautto, Mikko. 2004. Syntyvyyteen vaikuttaminen [Influencing fertility]. Pp. 31-50 in Väestökehitykseen vaikuttaminen - tulisiko syntyvyyttä ja maahanmuuttoa lisätä? Tulevaisuusselonteon liiteraportti 3, edited by Mikko Kautto. Valtioneuvoston kanslian julkaisusarja, No. 31/2004. Helsinki: Valtioneuvoston kanslia. Accessed on March 3, 2008. Available online at

http://www.vnk.fi/julkaisukansio/2004/j31-vaestokehitykseen-vaikuttaminen_pdf/fi.pdf

Kautto, Mikko. 2004. Väestökehitykseen vaikuttamista koskevat päätelmät [Conclusions concerning the influencing on population development]. Pp. 116-33 in Väestökehitykseen vaikuttaminen - tulisiko syntyvyyttä ja maahanmuuttoa lisätä? Tulevaisuusselonteon liiteraportti 3, edited by Mikko Kautto. Valtioneuvoston kanslian julkaisusarja, No. 31/2004. Accessed on March 3, 2008. Helsinki: Valtioneuvoston kanslia. Available online at

http://www.vnk.fi/julkaisukansio/2004/j31-vaestokehitykseen-vaikuttaminen /pdf/fi.pdf

Kontula, Osmo. 2004. Perhepolitiikka käännekohdassa: perhebarometri 2004 [Family policy at a turning point: family survey 2004]. Katsauksia E, No. 18. Helsinki: Väestöliitto, Väestöntutkimuslaitos. 155 pp. ISBN 951-9450-11-4. Accessed on Jan. 11, 2008. Available online at

http://www.vaestoliitto.fi/mp/db/file library/x/IMG/76644/file/Perhebaro04.pdf

Kontula, Osmo and Anneli Miettinen. 2005. Synthesis report on demographic behaviour, existing population related policies and expectations men and women have concerning the state. Working papers E, No. 19/2005. Helsinki: The Population Research Institute, Väestöliitto, The Family Federation of Finland. 151 pp. ISBN 951-9450-13-0. Dialog Work Package 4, Report D 15. Accessed on Nov. 28, 2006. Available online at http://www.vaestoliitto.fi/mp/db/file_library/x/IMG/34162/file/DialogD15.pdf

Korhonen, Sirpa. 2006. Tyhjeneekö Kainuu kokonaan väestöstä? [Is Kainuu losing all its population?]. Pp. 161-72 in Munttaako Onni maalle? Suurten ikäluokkien valinta: Muuttoliikesymposium 2005, Turku 23.-24.11, edited by Elli Heikkilä. Siirtolaisuustutkimuksia, No. A 28. Turku: Siirtolaisuusinstituutti.

Kosunen, Elise. 2006. Seksuaaliterveyden edistäminen Suomessa: muistio seksuaali-ja lisääntymisterveyden edistämisen toimintaohjelmaa laativaa työryhmää varten [Promoting sexual health in Finland: memorandum for the working group dealing with the action program on sexual and reproductive health]. Helsinki: STAKES Sosiaali- ja terveysalan tutkimus- ja kehittämiskeskus. 56 pp. Työpapereita, No. 5, 2006. ISBN 951-33-1673-4. Accessed on Nov. 27, 2007. Available online at http://www.stakes.fi/verkkojulkaisut/tyopaperit/Tp5-2006.pdf.

Laine, Veli. 2004. Kannustaako vuoden 2005 eläkeuudistus? [Does the pension reform in 2005 encourage to continue to work]. Pp. 187-96 in Hyvinvointi ja työmarkkinoiden eriytyminen, edited by Reino Hjerppe and Heikki Räisänen. VATT-julkaisuja, No. 40. Helsinki: VATT Valtion taloudellinen tutkimuskeskus.

Marttinen, Jouni. 2006. Harmaantuva Varsinais-Suomi [Greying Southwest Finland]. Pp. 150-60 in Muuttaako Onni maalle? Suurten ikäluokkien valinta: Muuttoliikesymposium 2005, Turku 23.-24.11, edited by Elli Heikkilä. Siirtolaisuustutkimuksia, No. A 28. Turku: Siirtolaisuusinstituutti. 
Mattila, Markku. 2005. Sterilointipolitiikka ja romanit Suomessa vuosina 1950-1970 [Sterilization policy and the roma in Finland in 1950-1970]. Pp. 402-52 in Vieraat kulkijat - tutut talot: näkulmia etnisyyden ja köyhyyden historiaan Suomessa, edited by Antti Häkkinen, Panu Pulma, and Miika Tervonen. Historiallinen arkisto, No. 120. Helsinki: Suomalaisen Kirjallisuuden Seura.

Miettinen, Anneli. 2005. Time or money? The preference of family policy measures among 20-40-year old Finnish men and women. Pp. 33-43 in Contributions from PPAS at the European Population Conference, Warsaw, Poland, 26-30 August 2003. BiB, No. 3, 2005. Wiesbaden: BiB Federal Institute for Population Research.

Moisio, Pasi. 2006. Kasvanut polarisaatio lapsiperheiden parissa [Increased polarization among families with children]. Pp. 36-56 in Suomalaisten hyvinvointi 2006, edited by Mikko Kautto. Helsinki: STAKES Sosiaali- ja terveysalan tutkimus- ja kehittämiskeskus.

Nurminen, Johanna and Turtiainen, Kati (ed.) 2006. Jyväskylän kaupungin, Jyväskylän maalaiskunnan, Laukaan ja Muuramen monikulttuurisuusohjelma [Regional program on multiculturalism of the city of Jyväskylä, Jyväskylä rural municipality, and the rural municipalities of Laukaa and Muurame ]. Jyväskylän sosiaali- ja terveyspalvelukeskuksen julkaisuja, No. 1/2006. Jyväskylä: Jyväskylän kaupunki. 187, [8] pp. ISBN 952-5332-86-1.

Parjanne, Marja-Liisa. 2004. Väestön ikärakenteen muutoksen vaikutukset ja niihin varautuminen eri hallinnonaloilla [The changing age structure of the population and preparing for itse effects in the different sectors of administration]. Sosiaali- ja terveysministeriön selvityksiä, No. 28, 2004. Helsinki: Sosiaali- ja terveysministeriö. 73 pp. ISBN 952-00-1577-9.

Pulma, Panu. 2005. Ongelmavähemmistöstä vähemmistöongelmaksi: Suomen romanipolitiikka 2. maailmansodan jälkeisellä ajalla [From problem minority to minority problem: Finnish roma policy after World War II]. in Vieraat kulkijat - tutut talot, edited by Antti Häkkinen, Panu Pulma, and Miika Tervonen. Historiallinen arkisto, No. 120. Helsinki: Suomalaisen Kirjallisuuden Seura.

Pulma, Panu. 2006. Suljetut ovet: Pohjoismaiden romanipolitiikka 1500-luvulta EUaikaan [Closed doors: Nordic Romani policy from the 16th century to the EU era]. Historiallisia tutkimuksia No. 230. Helsinki: Suomalaisen Kirjallisuuden Seura. 237 pp. ISBN 951-746-785-0. Sum. in Eng.

Pulma, Panu. 2006. Ongelmavähemmistöstä vähemmistöongelmaksi: Suomen romanipolitiikka 2. maailmansodan jälkeisellä ajalla [From a problem minority to a minority problem: Finland's romany policy after World War II]. Pp. 369-401 in Vieraat kulkijat - tutut talot: näkökulmia etnisyyden ja köyhyyden historiaan Suomessa, edited by Antti Häkkinen, Panu Pulma, and Miika Tervonen. Historiallinen Arkisto, No. 120. Helsinki: Suomalaisen Kirjallisuuden Seura.

Rantalaiho, Minna. 2004. Mitä päivähoitokeskustelu kertoo suomalaisesta perhe- ja lapsipolitiikasta? [What the discussion on child day care tells about Finnish child and family policy?]. Sosiaaliturva 92(17):18-21. 
Salmi, Minna. 2006. Syntyvyys vai työllisyysaste? [Fertility or employment rate]. Yhteiskuntapolitiikka 71(4):416-23.

Sisäasiainministeriö [Ministry of the Interior]. 2006. Sisäasiainministeriön strategia maahanmuuttohallinnon ja ulkomaalaislainsäädännön kehittämiseksi: työryhmän ehdotus [Strategy of the Ministry of the Interior to develop the immigration administration and aliens legislation: a proposal of the working group]. Sisäasianministeriön julkaisuja, No. 30/2006. Helsinki: Sisäasiainministeriö. 50, [1] pp. ISBN 952-491-013-6. Accessed on Dec. 27, 2007. Available online at http://www.intermin.fi/intermin/biblio. nsf/95B10F6D51E1484EC2257186002873DE/\$file/302006.pdf. Sum. in Swe.

Sosiaali- ja terveysministeriö [Ministry of Social Affairs and Health]. 2006. Seksuaalija lisääntymisterveyden edistäminen: toimintaohjelma 2007-2010 [Promoting sexual and reproductve health: action program 2007-2010]. Sosiaali- ja terveysministeriön selvityksiä. 83, 2006. Helsinki: Sosiaali- ja terveysministeriö. 169 pp. ISBN 978-95200-2137-5. Accessed online on Nov. 28, 2007. Available at http://www.stm.fi/Resource. phx/publishing/store/2006/12/pr1169630707750/passthru.pdf

Sosiaali- ja terveysministeriö [Ministry of Social Affairs and Health]. 2006. Lapsiperheiden toimeentuloedellytysten kehittäminen [Developing the income offamilies with children: a summary report by the coordinating group]. Sosiaali- ja terveysministeriön selvityksiä, No. 31, 2006. Helsinki: Sosiaali- ja terveysministeriö. 31, [2] pp. ISBN 952-00-2070-5. Accessed on Dec. 28, 2007. Available online at http://www.stm.fi/Resource.phx/publishing/store/2006/11/hl1164006045033/passthru.pdf. Sum. in Swe and Eng.

Sosiaali- ja terveysministeriö [Ministry of Social Affairs and Health]. 2005. Lapsille sopiva Suomi: YK:n yleiskokouksen lasten erityisistunnon edellyttämä Suomen kansallinen toimintasuunnitelma [A Finland fit for children: the national Finnish plan of action called for by the special session on children of the UN General Assembly]. Sosiaali- ja terveysministeriön julkaisuja, No. 5, 2005.Helsinki: Sosiaali- ja terveysministeriö. 72 pp. ISBN 951-00-1490-X. Accessed on Jan. 11, 2008. Available online at http://www.stm.fi/Resource.phx/publishing/store/2005/05/cd1116309940724/passthru.pdf Published also in Swe. and Eng.

Söderling, Ismo. 2004. Finland in Sweden's footsteps: differences and similarities in immigration and integration policies. Pp. 42-51 in Power and control: perspectives on integration and multiculturalism in Europe, edited by Kimi Kärki. Publications of The Population Research Institute, Series D 43/2004 \& Publications of the Doctoral Program of Cultural Interaction and Integration, No. 8. Helsinki: The Family Federation of Finland, The Population Research Institute \& Turku: University of Turku, The Graduate School on Cultural Interaction and Integration and the Baltic Sea Region.

Söderling, Ismo. 2004. Une politique d'integration plus active pour un pays d'immigration de fraîche date. Pp. 172-75 in Usages sociaux du temps et migrations = les familles a la croisee de l'espace et du temps: actes de la conférence Europeenne, Comité économique et social Européen, Bruxelles, 12-13 janvier 2004. Bruxelles: COFACE - DG Emploi et Affaires sociales de la Commission Européenne. Accessed on Nov. 21, 2006. Available online at http://www.unaf.fr/IMG/pdf/Les familles a la croisee de 1 espace et du temps.pdf 
Söderling, Ismo. 2004. Väestöpolitiikka historiallisessa tarkastelussa ja eurooppalaisessa vertailussa [Population policy considered historically and in European comparison]. Pp. 13-19 in Väestökehitykseen vaikuttaminen - tulisiko syntyvyyttä ja maahanmuuttoa lisätä: tulevaisuusselonteon liiteraportti 3, edited by Mikko Kautto. Valtioneuvoston kanslian julkaisusarja. 31/2004. Accessed on March 7, 2008. Helsinki: Valtioneuvoston kanslia. Available online at http://www.vnk.fi/julkaisukansio/2004/j31-vaestokehitykseen-vaikuttaminen_pdf/fi.pdf

Söderling, Ismo and Elina Laitalainen. 2005. Summary of demographic trends and policy implications presented in the national reports. Working papers, E, No. 20/2005. Helsinki: The Population Research Institute, Väestöliitto, The Family Federation of Finland. 62 pp. ISBN 951-9450-21-1. Dialog, Work Package 4, Report D 14. Accessed on Nov. 28, 2006. Available online at

http://www.vaestoliitto.fi/mp/db/file library/x/IMG/34161/file/DialogD14.pdf

Takala, Pentti and Helka Hytti. 2005. Mininum parental allowance payments received by Finnish mothers. Yearbook of Population Research in Finland 41:47-60.

Takala, Pentti. 2005. Perheen muutos ja pohjoismainen perhepolitiikan malli [The change in families and the Nordic family policy model]. Pp. 20-56 in Onko meillä malttia sijoittaa lapsiin?, edited by Pentti Takala. Helsinki: Kelan tutkimusosasto.

Tanner, Arno. 2006. Kasvaako työvoimatarve? - vastaako maahanmuuttopolitiikka? [Is the need for labor growing? - does the migration policy respond?]. Pp. 185-95 in Muuttaako Onni maalle? Suurten ikäluokkien valinta: Muuttoliikesymposium 2005, Turku 23.-24.11, edited by Elli Heikkilä. Siirtolaisuustutkimuksia, No. A 28. Turku: Siirtolaisuusinstituutti.

Tanni, Katri. 2005. Siirtolaispolitiikan moraalista Valkoisen Australian historian valossa [On the morality of immigrant policy in the light of the history of white Australia]. Lähde - historiatieteellinen aikakauskirja 2(1):15-21.

Taskinen, Sirpa, Pasi Moisio, and Hannele Sauli. 2005. Perhepolitiikan suuntaviivat [Trends in family policy]. Pp. 16-40 in Lapsiperheiden taloudellisen tilanteen kehitys Suomessa 1990-2002, edited by Pasi Moisio. Raportteja, No. 4/2005. Helsinki: STAKES Sosiaali- ja terveysalan tutkimus- ja kehittämiskeskus. Accessed on Jan. 16, 2008. Available online at http://www.stakes.fi/verkkojulkaisut/raportit/Ra4-2005.pdf.

Tuominen, Eila. 2005. Ikääntyneiden työllisyys ja työhön kannustava ikäpolitiikka [The employment of the aged and the age policy inciting to work]. Pp. 191-6 in Kymmenvuosikatsaus 2005: teemana yritystoiminta, edited by Jaakko Autio. Helsinki: Tilastokeskus.

Turunen, Teemu, Anneli Miettinen, and Ismo Söderling. 2006. Country report: Finland: population related policies and general attitudes. Dialog, WP 4. Helsinki: Väestöliitto, The Population Research Institute. 37 pp. Accessed on Feb. 20, 2008. Available online at http://www.vaestoliitto.fi/mp/db/file library/x/IMG/52043/file/D13Finland.pdf

Työministeriö [Ministry of Labour]. 2005. Työryhmän ehdotus hallituksen maahanmuuttopoliittiseksi ohjelmaksi [Working group proposal for Government's immigration 
policy program]. Työhallinnon julkaisu, No. 355. Helsinki: Työministeriö. 45, [1] pp. ISBN 951-735-956-X. Accessed on Dec. 28, 2007. Available at

http://www.mol.fi/mol/fi/ $/ 99$ pdf/fi/06 tyoministerio/06 julkaisut/07 julkaisu/thj355.pdf

Työministeriö [Ministry of Labour]. 2006. Hallituksen ulkosuomalaispoliittinen ohjelma 2006-2011 = regeringens utlandsfinländarpolitiska program $=$ government policy programme for expatriate Finns. Työhallinnon julkaisu, No. 369. Helsinki: Työministeriö. ISBN 952-490-026-2. Accessed on Feb. 17, 2008. Available online at http://www.mol.fi/mol/fi/99 pdf/i//06 tyoministerio/06 julkaisut/07 julkaisu/thj369.pdf.

Valtioneuvosto [Finnish Government]. 2006. Hallituksen maahanmuuttopoliittinen ohjelma: valtioneuvoston periaatepäätös $19.10 .2006=$ regeringens invandrarpolitiska program: stadsrådets principbeslut 19.10.2006 = government migration policy programme : government resolution 19.10.2006. Työhallinnon julkaisu, No. 371. Helsinki: Työministeriö. 45, 46, 47, [13] pp. ISBN 952-490-037-8. Accessed on Dec. 28, 2007. Available online at

http://www.mol.fi/mol/fi/99 pdf/fi/06 tyoministerio/06 julkaisut/07 julkaisu/thj371.pdf

Valtioneuvoston kanslia [Prime Minister's Office]. 2004. Hyvä yhteiskunta kaikenikäisille: Valtioneuvoston tulevaisuusselonteko väestökehityksestä, väestöpolitiikasta ja ikärakenteen muutokseen varautumisesta [Finland for people in all ages: Government report on the future: demographic trends, population policy, and preparation for changes in the age structure]. Valtioneuvoston kanslian julkaisusarja, No. 27/2004. Helsinki: Valtioneuvoston kanslia. 59 pp. ISBN 952-5354-69-5. Accessed on March 3, 2008. Available online at

http://www.vnk.fi/julkaisukansio/2004/j27-28-34-hyvae-yhteiskunta-kaikenikaeisille/ pdf/fi.pdf. Available also in Swedish and English.

Valtioneuvoston kanslia [Prime Minister's Office]. 2006. Ikärakenteen muutokseen varautuminen: tulevaisuusselonteon linjausten eteneminen vuonna 2005 [To prepare for the change in the age structure: the progress of the plans of the Government Report on Future]. Valtioneuvoston kanslian raportteja, No. 5/2006. Helsinki: Valtioneuvoston kanslia. 60 pp. Accessed on Dec. 28, 2007. Available online at http://www.vnk.fi/julkaisukansio/2006/r05-ikarakenteen-muutokseen-varautuminen/pdf/fi.pdf. Sum. in Swe.

Väestöliitto. 2006. Väestöliiton seksuaaliterveyspoliittinen ohjelma [The sexual health policy program of Väestöliitto, The Family Federation of Finland]. Helsinki: Väestöliitto. 62 pp. ISBN 951-9450-30-0. Accessed on Nov. 27, 2007. Availabe online at http://www.vaestoliitto.fi/mp/db/file_library/x/IMG/52449/file/VLSekstervpolohjelma.pdf

Väestöliitto. 2004. Väestöpoliittinen ohjelma [Population policy program]. Helsinki: Väestöliitto. 70 pp.951-9450-04-1. Accessed on Jan. 11, 2008. Available online at http://www.vaestoliitto.fi/mp/db/file library/x/IMG/13591/file/vpohjelma_lopullinenpdf.pdf.

A separate summary in English. 


\section{N. METHODS OF RESEARCH AND ANALYSIS INCLUDING MODELS}

Rusanen, Jarmo. 2006. Paikkatiedosta on hyötyä myös kuntasuunnittelussa [GIS can be utilized in municipalitiy planning]. Kuntapuntari (3):23-5.

\section{O. THE PRODUCTION OF POPULATION STATISTICS}

(No citations)

\section{P. PROFESSIONAL MEETINGS AND CONFERENCES}

ETMU Etnisten suhteiden ja kansainvälisen muuttoliikkeen tutkimuksen seura [The Society for the Study of Ethnic Relations and International Migration]. 2004. Etniset suhteet ja kansainvälinen liikkuvuus: tutkimuksen nykytila Suomessa: 1. ETMU-päivät, 29.-30.10.2004, SocKom, Helsinki : abstraktit = ethnic relations and international mobility: the current state of research in Finland: 1st ETMU days, October 29-30, 2004, SocKom, Helsinki: abstracts = etniska relationer och internationell migration: forskningens nuläge i Finland: 1. ETMU-dagarna, 29-30.10.2004, SocKom, Helsingfors. Helsinki: Etnisten suhteiden ja kansainvälisen muuttoliikkeen tutkimuksen seura. $37 \mathrm{pp}$.

Heikkilä, Elli (ed.). 2005. Monikulttuuriset avioliitot sillanrakentajina: vuoden 2005 seminaariraportti [Multicultural marriages as bridge builders: seminar report 2005]. Web Reports, No. 11. Turku: Siirtolaisuusinstituutti. 64 pp. Accessed on Feb. 21, 2008. Available online at http://www.migrationinstitute.fi/pdf/webreports11.pdf.

Heikkilä, Elli (ed.). 2006. Muuttaako Onni maalle? Suurten ikäluokkien valinta: muuttoliikesymposium 2005, Turku 23.-24.11. [Does Onni move to the countryside? The choice of the baby boom cohorts: migration symposium in 2005 on November 23-24]. Siirtolaisuustutkimuksia A, No. 28. Turku: Siirtolaisuusinstituutti. 209 pp. ISBN 951-9266-85-2.

Heikkilä, Elli, Ritva Viertola-Cavallari, Päivi Oksi-Walter, and Jonna Roos. 2004. Monikulttuuriset avioliitot sillanrakentajina [Multicultural marriages as bridge builders]. 80 pp. Web Reports, No. 2. Turku: Siirtolaisuusinstituutti. Accessed on Feb. 21, 2008. Available online at http://www.migrationinstitute.fi/pdf/webreports2.pdf.

Hiltunen, Eija (ed.). 2006. Terveydenhuoltotutkimuksen päivät 2006: yksilö vai rakenteet, Kuopio 5.-6.10.2006: tutkimuspaperit [Health care research meeting 2006: an individual or structures, Kuopio, Oct. 5-6, 2006: papers]. STAKESin työpapereita, No. 26, 2006. Helsinki: STAKES Sosiaali- ja terveysalan tutkimus- ja kehittämiskeskus. Accessed on Nov. 27, 2007. Available at http://www.stakes.fi/verkkojulkaisut/tyopaperit/T26-2006-VERKKO.pdf

Sinisalo-Katajisto, Petra (ed.), with assistance from Katja Hirvasaho, and Edvard Hämäläinen. 2004. Russian-speaking immigrant population in Finland : seminar in Helsinki, 25-26 September 2003. Studia Slavica Finlandensia. 21. Helsinki: Institute for Russian and East European Studies. 228 pp. ISBN 951-707-107-8. In Eng., Rus. 
Söderling, Ismo (ed.). 2006. Väestöpolitiikan tulevaisuuden haasteet: Väestöliiton väestöpoliittinen seminaari 12.9.2003 Helsinki: esitelmät ja kommenttipuheenvuorot [The future challenges of population policy: Väestöliitto's population policy seminar on September 12, 2003, Helsinki: papers and comments]. Helsinki: Väestöliitto, Väestöntutkimuslaitos. 83 pp. ISBN 951-9450-35-1 (PDF). Accessed on Feb. 19, 2008. Available online at http://www.vaestoliitto.fi/mp/db/file library/x/IMG/54748/file/VLvaestopolseminaari2003.pdf

Vaarama, Marja. 2005. Kansallisen ikääntymisen foorumi 17.12.2004: raportti [The national forum on aging on Dec. 17, 2004: report]. Helsinki: STAKES Sosiaali- ja terveysalan tutkimus- ja kehittämiskeskus \& Suomen Akatemia. 81 pp. ISBN 951-331801-X. Accessed on Feb. 26, 2008. Available online at http:/groups.stakes.fi/NR/rdonlyres/EDBBB5C2-2C24-4D52-A3AC-3535E4D450DE/0/Kansallinen ikaant.pdf

Vaarama, Marja and Simo Koskinen. 2006. Toinen kansallisen ikääntymisen foorumi 11.11.2005 [The second national forum on aging on Nov. 11, 2005]. Helsinki: STAKES Sosiaali- ja terveysalan tutkimus- ja kehittämiskeskus. $87 \mathrm{pp}$. ISBN 951-33-1857-5. Accessed on Feb. 26, 2008. Available online at http://groups.stakes. fi/NR/rdonlyres/5FCDF0D5-CB31-417A-B0A8-D56471B9BD0E/0/kansallinenikaantymisfoorumi2005.pdf

\section{Q. BIBLIOGRAPHIES, DIRECTORIES AND OTHER INFORMATION SERVICES}

Engman, Max. 2004. Suomalaiset Venäjällä: lähdeopas = handledning till källor rörande finländare i Ryssland [The Finns in Russia: guide to sources]. Helsinki: Kansallisarkisto. 143 pp. ISBN 951-53-2652-4.

Haapakorpi, Arja. 2004. Maahanmuuttajaprojektit Uudellamaalla: selvitys hankkeista ja niiden vaikuttavuudesta, hyvistä käytännöistä sekä hyvien käytäntöjen valtavirtaistamisesta [Immigrant projects in Uusimaa: a report on projects and their effect, good practices, and mainstreaming of good practices]. Uudenmaan liiton julkaisuja, C, No. 50. Helsinki: Uudenmaan liitto. 27, [2] pp. ISBN 952-448-141-3. Accessed on Feb. 18, 2008. Available online at http://www.uudenmaanliitto.fi/modules/publishbank/ julkaisupankki_files/225_C50maahanmuuttajaprojektit.pdf

Mattila, Ulla-Maija. 2004. Bibliography of Finnish population studies 2003. Yearbook of Population Research in Finland 40:209-25.

Ruhanen, Milla and Tuomas Martikainen. 2006. Maahanmuuttajaprojektit: hankkeet ja hyvät käytännöt [Immigration projects and good practices]. Katsauksia, No. E 22/2006. Helsinki: Väestöliitto, Väestöntutkimuslaitos. 77 pp. ISBN 951-9450-40-8. Accessed on Feb. 15, 2008. Available online at http://www.vaestoliitto.fi/mp/db/file library/x/IMG/57020/file/Maahanmuuttajaprojektit.pdf

Työministeriö [Ministry of Labour]. 2004. Muuttoliikkeet ja etniset vähemmistöt Suomessa 1999-2004: tutkimukset ja tilastot [Migrations and ethnic minorities in Finland in 1999-2004: studies and statistics]. Työhallinnon julkaisu, No. 343. Helsinki: Työministeriö. 117 pp. ISBN 951-735-897-0. Accessed on Feb. 18, 2008. Available online at

http://www.mol.fi/mol/fi/99 pdf/fi/06 tyoministerio/06 julkaisut/07 julkaisu/thj343.pdf- 


\section{R. NEW PERIODICALS}

Finnish Journal of Ethnicity and Migration. Vol. 1, 2006->. Helsinki: Society for the Study of Ethnic Relations and International Migration (ETMU). Available online at http://etmu.fi/fjem/.

\section{S. OFFICIAL STATISTICAL PUBLICATIONS}

Official Statistics of Finland, Tilastokeskus [Statistics Finland], Helsinki

\section{Causes of death}

Kuolemansyyt $2003=$ dödsorsaker $=$ causes of death .2004 . Health, 2004, 1. Helsinki: Statistics Finland. 123 pp. ISBN 952-0467-378-9. In Fin., Swe., Eng.

Kuolemansyyt $2004=$ dödsorsaker $=$ causes of death .2005. Health, 2005, 1. Helsinki: Statistics Finland. 143 pp. ISBN 952-0467-506-4. In Fin., Swe., Eng.

Kuolemansyyt $2005=$ dödsorsaker $=$ causes of death. 2006. Health, 2006. Helsinki: Statistics Finland. 138 pp. ISBN 952-0467-646-X. In Fin., Swe., Eng..

\section{Economic activity}

Väestön taloudellinen toiminta 1950-2000 = befolkningens ekonomiska verksamhet = economic activity of the population. 2005. Population, 2005, 4. Helsinki: Statistics Finland. 209 pp. ISBN 952-467-451-3. In Fin., Swe., Eng.

\section{Families}

Perheet $2003=$ familjer $=$ families. 2004. Population, 2004, 8. Helsinki: Statistics Finland. [179] pp. ISBN 952-467-370-3. In Fin., Swe., Eng.

Perheet $2004=$ familjer $=$ families. 2005. Population, 2005, 8. Helsinki: Statistics Finland. 184 pp. ISBN 952-467-508-0. In Fin., Swe., Eng.

Perheet $2005=$ familjer $=$ families. Population, 2006. Helsinki: Statistics Finland. 179 pp. ISBN 952-467-619-2. In Fin., Swe., Eng.

\section{Migration}

Ulkomaalaiset ja siirtolaisuus $2003=$ foreigners and international migration. 2004. Population, 2004, 6. Helsinki: Statistics Finland. 66 pp. ISBN 952-467-383-7. In Fin., Eng. Ulkomaalaiset ja siirtolaisuus $2004=$ foreigners and international migration. 2005. Population, 2005, 9. Helsinki: Statistics Finland. 70 pp. ISBN 952-467-509-9. In Fin., Eng.

Ulkomaalaiset ja siirtolaisuus 2005 = foreigners and international migration. 2006. Population, 2006. Helsinki: Statistics Finland. 71 pp. ISBN 952-467-626-5. In Fin., Eng.

\section{Population projections}

Väestöennuste kunnittain 2004-2040=befolkningsprognos kommunvis=population projection by municipality. Population 2004, 10. Helsinki: Statistics Finland. 101 pp. ISBN 952-467-415-7. In Fin., Swe., Eng. 


\section{Population size}

Väkiluku kunnittain ja suuruusjärjestyksessä 31.12.2003 = befolkning kommunvis och $i$ storleksordning 31.12.2003 [Population by municipality and by the size of population in municipalities on December 31, 2003]. 2004. Population, 2004, 2. Helsinki: Statistics Finland. 36 pp. ISBN 952-467-274-X. In Fin., Swe., Eng.

Väkiluku kunnittain ja suuruusjärjestyksessä 31.12.2004 = befolkning kommunvis och i storleksordning 31.12.2004 [Population by municipality and the size of population in municipalities on December 31, 2004]. 2005. Population, 2005, 2. Helsinki: Statistics Finland. 32 pp. ISBN 952-467-412-2. In Fin., Swe.

Väkiluku kunnittain ja suuruusjärjestyksessä 31.12.2005=befolkning kommunvis och $i$ storleksordning 31.12.2005 [Population by municipality and by the size of population in municipalities on December 31, 2005]. 2006. Population, 2006. Helsinki: Statistics Finland. 32 pp. ISBN 952-467-537-4. In Fin., Swe.

\section{Population structure}

Väestörakenne ja väestönmuutokset kunnittain $2003=$ befolkningens sammansättning och befolkningsförändringar kommunvis = population structure and vital statistics by municipality. 2004. Population, 2004, 4. Helsinki: Statistics Finland. 216 pp. ISBN 952-467-315-0. In Fin., Swe., Eng.

Väestörakenne ja väestönmuutokset kunnittain $2004=$ befolkningens sammansättning och befolkningsförändringar kommunvis = population structure and vital statistics by municipality. 2005. Population, 2005, 5. Helsinki: Statistics Finland. 217 pp. ISBN 952-467-459-9. In Fin., Swe., Eng.

Väestörakenne ja väestönmuutokset kunnittain 2005=befolkningens sammansättning och befolkningsförändringar kommunvis=population sructure and vital statistics by municipality. 2006. Population, 2006. Helsinki: Statistics Finland. 213 pp. ISBN 952-467-598-6. In Fin., Swe., Eng.

\section{Vital statistics}

Väestönmuutokset $2002=$ befolkningsförändringar $=$ vital statistics. 2004. Population, 2003, 11. Helsinki: Statistics Finland. 154 pp. ISBN 952-467-255-3. In Fin., Swe., Eng.

Väestönmuutokset $2003=$ befolkningsförändringar $=$ vital statistics. 2004. Population. 2004, 9. Helsinki: Statistics Finland. 154 pp. ISBN 952-467-377-0. In Fin., Swe., Eng.

Väestönmuutokset $2004=$ befolkningsförändringar = vital statistics. 2005. Population. 2005, 10. Helsinki: Statistics Finland. 164 pp. ISBN 952-467-514-5. In Fin., Swe., Eng.

2006. Väestönmuutokset $2005=$ befolkningsförändringar=vital statistics. Helsinki: Statistics Finland. 166 pp. ISBN 952-467-645-1. In Fin., Swe., Eng.

\section{Quarterly vital statistics}

Väestön neljännesvuositilasto = kvartalsstatisk över befolkning [Quarterly vital statististics]. 2004-2006. Helsinki. In Fin., Swe. 


\section{Population statistics and projections by other institutions}

Finnäs, Fjalar. 2004. Finlandssvenskarna 2002: en statistisk rapport [The Swedish speaking Finns 2002: a statistical report]. Finlandssvensk rapport, No. 41. Helsingfors: Svenska Finlands folkting. 56 pp. ISBN 952-9700-42-3.

Kansaneläkelaitos [The Social Insurance Institution of Finland]. 2006. Väestöennuste 2004-2075 = population projection Finland 2004-2075. Kansaneläkelaitoksen aktuaarijulkaisuja, No. 6. Helsinki: Kansaneläkelaitos. 20 pp. ISBN 951-669-692-9. Accessed on Nov. 21, 2007. Available on line at http://www.kela.fi/it/kelasto/kelasto. nsf/NET/290506132011AS/\$File/Väestöennuste\%202004-2075.pdf?OpenElement

Miettinen, Anneli. 2004. Population data on Finland 1900-2003. Yearbook of Population Research in Finland 40:227-34

Miettinen, Anneli. 2005. Population data on Finland 1900-2004. Yearbook of Population Research in Finland 41:191-98.

Miettinen, Anneli. 2006. Population data on Finland 1900-2005. Finnish Yearbook of Population Research 42(2006):161-70.

STAKES Sosiaali- ja terveysalan tutkimus- ja kehittämiskeskus [National Research and Development Centre for Welfare and Health]. Vuosittaiset tilastotiedotteet synnyttäjistä, synnytyksistä, vastasyntyneistä, raskaudenkeskeytyksistä, steriloinneista ja hedelmöityshoidoista [Annual statistical summaries on parturients, deliveries, births, induced abortions, sterilisations, and IVF treatments]. Accessed on Feb. 19, 2008. Available online at http://www.stakes.fi/FI/tilastot/aiheittain/Lisaantyminen/index.htm.

Väestörekisterikeskus [Population Register Centre]. Suomen asukasluku: vuodenvaihde $=$ Finlands invånartal vid årskiftet [The size of the Finnish population: turn of the year]. Accessed on Feb. 19, 2008. Available online at http://www.vrk.fi/vrk/home.nsf/pages/ 60686ADEEFF0901FC225731B00425BEC?opendocument. [Annual statistics].

\section{Sources}

ARTO Reference Database of Finnish Articles, accessed on Nov. 9, 2007-Feb. 1, 2008.

FENNICA National Bibliography of Finland https://fennica.linneanet.fi/ , accessed on Nov. 9, 2007-Feb. 12, 2008.

Publications of the Population Research Unit, Department of Sociology, University of Helsinki

http://www.valt.helsinki.fi/sosio/pru/publications.htm, accessed on Nov. 9, 2007

Popline database http://db.jhuccp.org/ics-wpd/popweb/ , accessed on October 19, 2007

PubMed Medline http://www.ncbi.nlm.nih.gov/sites/entrez, accessed on October 22, 2007

Sociological Abstracts database, accessed on September 6, 2007

The collections of the library of the Population Research Institute of Väestöliitto, Helsinki 


\section{Author Index}

Aatola, Leena - H2

Ahlgren-Leinvuo, Hanna - H2

Ahonen, Hilkka - E

Aikio, Aslak - I

Ainsaar, Mare - H2

Akar, Sylvia - G

Akhlaq, Ahmad - K

Alanen, Aku - H1

Alexander, Sophie - E

Alho, Juha - E

Alkio, Paula - F, L

Andersen, O. - E

Anttonen, Anneli - M

Apter, Dan - F

Arber, S. - L

Aromaa, Arpo - L

Avendaño, M. - E

Bajos, Nathalie - F

Barego, Noël - E

Bartley, M. - L

Berg, Cynthia - E

Berg, Stig - E

Björklund, Krister - H1, J

Bladh, Gabriel (ed.) - I

Bladh, Gabriel - I

Blomberg-Kroll, Helena - K

Blomgren, J. - E, J

Bopp, M. - E

Borgan, J.K. - E

Borrell, C. - E

Borrell, L.N. - E

Bos, V. - E

Bouvier-Colle, Marie-Hélène - E

Breat, Gerard - E

Brunner, E. - L

Buekens, Pierre - E

Burström, Bo - L

Böckerman, Petri - E

Capewell, Simon - E

Cardano, M. - E

Carlsson, Christina - G

Chandola, T. - L

Clarke, Kris - L

Coleman, David - D

Costa, G. - E

Critchley, Julia - E

Dal, Espen - L

Dalstra, J.A. - L

Deboosere, P. - E

Deev, Alexander D. - E

Degni, F. - F
Deneux-Tharaux, Catherine - E

Desplanques, G. - E

Diez Rouax, A.V. - E

Donkin, A. - E

Dubikaytis, Tatyana - F

Durham, Helen - H2

Dykes, J. - L

Einasto, Heili - M

Elo, Irma T. - E

Elomaa, Hanna - J

Elovainio, M. - E

Elstad, J.I. - L

Engman, Max - I, Q

Eronen, Hanna - F

Ervasti, Heikki - H1

Etelä-Suomen lääninhallitus - M

Etelä-Suomen maakuntien liittouma - B

ETMU - P, R

Fedorova, Natalia - L

Ferrie, Jane E. - E

Finnäs, Fjalar - E, K, L, S

Forsander, Annika - H1, K

Forssén, K. - E, F, M

Fritzell, Johan - L

Gadeyne, S. - E

Gissler, Mika - E, F

Glickman, M. - E

Guillaume, Agnès - F

Haapakorpi, Arja - Q

Haataja, Anita - M

Haavio-Mannila, Elina - F, G, L

Hablicsek, László - H1

Haimi, Olavi - F

Hakamies, Pekka - H1

Hakamies, Pekka (ed.) - H2

Hakovirta, Mia - K, M

Haldre, Kai (ed.) - L

Halme, Timo - $\mathrm{H} 2$

Harding, S. - E

Harkonmäki, Karoliina - L

Harper, Margaret - E

Hassani, Kobra Falah - F

Hassi, Juhani - L

Hautala, Johanna - H1

Head, J. - L

Hegyesi, Adrienn - H1

Heikkilä, Elli- G, H1, H2, K, P

Heikkilä, Elli (ed.) - P

Heikkinen, Eino - E, L

Heikkinen, Riitta-Liisa - E

Heinonen, Seppo - F

Heiskanen, Nonna - F

Helakorpi, Satu - L 
Helander, Mika - H1

Helasoja, Ville - L

Helén, Ilpo - M

Helenius, Hans - E

Hellsten, Sirkku K. - M

Hemminki, Elina - F

Hemström, Örjan - E

Hetemaa, Tiina - E

Hiilamo, Heikki - M

Hiltunen, Eija (ed.) - P

Hiltunen, Juha - I

Hinkula, Marianne - E, F

Hintikka, Jukka - E

Hokkanen, Mari - H1

Honkanen, Ossi - D

Hovatta, Outi - F

Huisman, M. - E

Huju, Päivi - J

Hunnakko, Pekka - H2

Huohvanainen, Mauno - E

Huoponen, Kirsi - L

Huovari, Janne - J, K

Hytti, Helka - K, M

Hyvönen, Heli - H1

Hämynen, Tapio - I

Hämäläinen, Kari - H1, K

Härkänen, Tommi T. - L

Härkönen, Juho - G

Hätälä, Johanna - K

Iivari, Juhani - H1

Immonen-Räihä, Pirjo - E

Impinen, Antti (ed.) - E

Ishizaki, M. - L

Isoniemi, Henna - G

Itäpuisto, Timo - H2

Jaakkola, Magdalena - H1, K

Jasinskaja-Lahti, Inga - H1, L

Johansson, Edvard - E

Jokisaari, Selene - M

Joronen, Tuula $-\mathrm{K}$

Jousilahti, Pekka - E

Joutsenniemi, Kaisla - L

Junila, Marianne - H1

Junila, Marianne (ed.) - H1

Juntto, Anneli - H1

Juonala, Markus - L

Järvinen, Taru - H1, K

Järvinen-Tassopoulos, Johanna - G

Kaaja, Risto - F

Kaarisalo, Minna - E

Kagamimori, S. - L

Kahila, Petri - H2

Kallio, Olavi - K
Kallunki, Marjo - E

Kangas, Olli - M

Kangasharju, Aki - B, H1, K

Kangaspuro, Markku - H1

Kannisto, Jari - K

Kansaneläkelaitos - S

Kari, Matti - M

Karinen, Risto - K

Karisto, Antti - H1, J, L

Karisto, Antti (ed.) - J

Karkola, Kari O. - E

Karppi, Ilari (ed.) - H1

Kasmel, Anu - L

Kauhanen, Jussi - E

Kauhanen, Laura - E

Kauppila, Antti - E, F

Kauppinen, T. - E

Kautto, Mikko - D, F, H1, M

Kautto, Mikko (ed.) - J, K, M

Kavén, Pertti - H1

Kepsu, Kaisa - H1

Keränen, Heikki - B

Keskimäki, Ilmo - E, L

Keskinen, Jouni - I

Kesseli, Katja - F, L

Ketokivi, Kaisa-G

Ketola, Tanja - J

Ketonen, Matti $-\mathrm{E}$

Kiander, Jaakko - K

Kilpeläinen, Päivi - H2

Kinnunen, Tarja I. - F

Kirichenko, Svetlana - F

Kirkkola, Anna-Leena - F

Kirmo, Outi - J

Kivimäki, M. - E, L

Klemetti, Reija - F

Klumbiene, Jurate - L

Koivusilta, L. - F

Kokko, Karoliina - H2

Kondratieva, Elena - H1

Kontula, Osmo - F, L, M

Koponen, Päivikki - F, L

Korhonen, Sirpa - M

Korkalainen, Sari - H2

Korkiasaari, Jouni - H1

Koskenvuo, Markku - L

Koskimäki, Ville - K

Koskinen, S. - D, E, L

Koskinen, Simo - P

Kosunen, Elise - F, L, M

Kotiranta, Mikko - H2

Kotkavuori, Jouni - F

Kravdal, Øystein - E 
Kuhanen, Jan - I

Kukko, Heikki - G

Kultalahti, Olli (ed.)- H1

Kumpula, Heli (ed.) - E

Kumpulainen, Mikko - H2

Kunst, A.E. - E, L

Kunttu, Kristiina - F

Kunz, Jan - J

Kupiszewska, Dorota - H1

Kupiszewski, Marek - H2

Kuropjatnik, Marina - I

Kutznetsova, Olga - F

Kuulasmaa, Kari - E

Kuvaja, Christer (ed.) - I

Kyhä, Henna - K

Kyntäjä, Eve - H1

Kytö, Hannu - H2

Kyyrönen, Pentti - F

Laakso, Mauri (ed.) - L

Laakso, Seppo - D, H2

Laaksonen, M. - L

Laasonen, Pentti - I

Laatikainen, Tiina - E

Laes, Esko - L

Lahelma, E. - L

Lahti, Raimo - E

Lahti-Argutina, Eila - H1

Laine, Antti - H1

Laine, Veli-M

Laitalainen, Elina - M

Lakka, Hanna-Maaria - E

Lang, Sonja - H1

Lankinen, Markku - K

Lappalainen, Tuuli $-\mathrm{L}$

Laurila, Hannu - K

Layte, Richard - E

Lehmijoki, Ulla - K

Lehtonen, Aapo - E

Lehtonen, Johannes - E

Leino-Arjas, P. - E, L

Leinonen, Johanna $-\mathrm{G}$

Leitzinger, Antero - I

Leppäluoto, Juhani - F

Leppämäki, Henna - F

Liebkind, Karmela - H1, L

Liinamo, Arja - L

Lindbohm, Marja-Liisa - F

Linna, Anne - E

Linnanmäki, Eila - I, L

Loikkanen, Heikki A. - H2

Lonkila, Markku - H2

Looman, C.W.N. - L

Lounamaa, Anne (ed.) - E
Lunetta, Philippe (ed.) - E

Luoto, Riitta - F, L

Luukkainen, Pekka - E

Lynch, John W. - E

Lyyra, Tiina-Mari - E

Lähteenmäki, Maria - I

Lähteenmäki, Maria (ed.) - H1

Lönnqvist, Jouko - E

Mackenbach, J.P.- E, L

Majamaa, Karoliina - E

Manderbacka, Kristiina - E, L

Mannila, Simo - H1, K

Marinacci, C. - E

Markkanen, Kirsi - K

Marmot, M. - L

Martelin, T. - E, L

Martikainen, P. -D, E, H1, J, L

Martikainen, Tuomas - H1, J, Q

Marttinen, Jouni - M

Mattila, Johanna - H2

Mattila, Kari - F

Mattila, Markku - M

Mattila, Ulla-Maija - Q

McKee, M. - E

McMichael, A.J. - E

Melby, Kari - G

Melegh, Attila - H1

Meskus, Mianna - I

Michikazu, S. - L

Miettinen, Anneli - F, M, S

Minder, C. - E

Moisala, Jutta - H1

Moisio, Pasi - G, M

Morikawa, Y. - L

Moring, Beatrice - I

Munter, Arja - H1

Murphy, Michael - D

Myrskylä, Pekka - H2, J, K

Myrskylä, Pekka (ed.) - J

Mähönen, Markku - E

Mäkelä, P. - E

Mäki, N. - E, H1, J, L

Männistö, Satu - F

Määttänen, Niku - E

Nakagawa, H. - L

Nannini, Angela - E

Nasermoaddeli, A. - L

Neubauer, Jörg - K

Nevalainen, Pasi - B

Niemelä, Matti - E

Nieminen, Mauri - D, F, H1, H2, J

Nihtilä, E. - E, J

Niinikoski, Marja-Liisa - K 
Nikander, Eivor (ed.) - L

Nikula, Minna - F

Nishi, N. - L

Nivalainen, Satu - B

Notkola, V. - E, F

Nurminen, Johanna (ed.) - M

Näyhä, Simo - E

Näyhä, Simo (ed.) - L

Oilinki-Nenonen, Pirkko - J

Oinonen, Eriikka - G

Ojanlatva, A. - F

Oksama, Heidi - F

Oksi-Walter, Päivi - P

Ollikainen, Virve - K

Ovaska, Esko - H2

Paajanen, Pirjo - F, G

Paananen, Maarit - K

Paananen, Seppo - H1

Paavola, Meri (ed.) - E

Pajunen, Pia - E

Pakarinen, Mikko - H1

Palosuo, Hannele - L

Parjanne, Marja-Liisa - D, M

Parkkinen, Pekka - K

Partanen, Jukka - I

Pehkonen, Aini - H1, H2, K

Pekkala, Sari - H1, K

Pelkonen, Margit - E

Peltola, Jarmo - I

Pennec, Sophie - D

Pensola, Tiina - E

Pentti, Jaana - E

Penttilä, Irmeli - J, L

Perheentupa, Antti - F, L

Perhoniemi, Riku - H1, L

Persson, Lars Olof - K

Pesonen, Tuula M. - E

Pesälä, Leena - G

Piekkola, Hannu - J

Pietilä, Kirsi - F

Pikkarainen, Maria - K

Pirkanmaan liitto - B, H2

Pirkola, Sami - L

Pitkänen, Pirkko - J

Plasència, A. - E

Polla, Matti - I

Poolamets, Olev - L

Poolamets, Olev (ed.) - L

Prskawetz, Alexia - F

Prättälä, Ritva - E, L

Pudule, Iveta - L

Puhakka, Mikko - K

Pukkala, Eero - E, F

Pukkila, Tarmo - J
Pulma, Panu - M

Pylkkänen, Anu - G

Raatikainen, Kaisa - F

Rahkonen, O. - E, H1, J, L

Raitakari, Olli T. - L

Rajantie, Jukka - L

Rantala, Heikki (ed.) - H1

Rantalaiho, Minna - M

Rantanen, Taina - E

Rapo, Markus - D, H2

Raunio, Mika - H1, K

Rautio, Mikko - L

Read, Sanna - E

Rees, Philip - H1

REFER group - E, L

Regidor, E. - E

Regushevskaya, Elena - F

Reid, A. - E

Rekonen, Petri - H1, H2, I

Renko, Marjo - E

Reunanen, Antti - E

Reuter, Anni - H1, K

Rimpelä, Arja - F, L

Rinne-Koski, Katja - H2

Ritakallio, V.-M. - F

Ritamies, Marketta - F

Ritvanen, Annukka - F

Roms, Jussi - I

Roos, E. - L

Roos, Jonna - P

Rosenbeck, Bente - G

Rotkirch, Anna - F, G

Ruhanen, Milla - Q

Rusanen, Jarmo - N

Rytkönen, Mika - L

Räsänen, Antti - J

Saarela, Jan - E, H1, J, K, L

Saari, Matti - B

Saarnio, Pekka - E

Saastamoinen, P. - L

Sahi, Timo - L

Sailas, Jukka - E

Salin, Milla - K

Salmenhaara, Perttu - H1

Salmi, Anna-Maria - H2

Salmi, Minna - M

Salminen, Heikki - H1

Salomaa, Veikko - E

Saloniemi, Antti - L

Samuelson, Jan - I

Santana, Paula - E

Sarlio-Lähteenkorva, Sirpa - L

Sarti, Cinzia - E

Sarvimäki, Matti - H1, K 
Satokangas, Reija - I

Sauli, Hannele - F, M

Savontaus, Marja-Liisa - L

SEdHA working group - L

Sekine, M. - L

Seppälä, Antti - H1

Shemeikka, R. - F, L

Shipley, M. - L

Shkolnikov, V. - E

Siegberg, Rita $-\mathrm{F}$

Sihto, Marita - L

Sihvo, Sinikka - F

Siiskonen, H. - F

Silventoinen, K. - L

Simpura, Jussi - J

Sinisalo, Timo - D

Sinisalo-Katajisto, Petra (ed.) - P

Sinko, Pekka (ed.) - K

Sintonen, Seppo - J

Sipilä, Jorma - M

Sipilä, Petteri - E, L

Sisäasiainministeriö - J, M

Sivenius, Juhani - E

Sjöblom-Immala, Heli - K

Skog, Irene - H1

Smith, Kirsten P. - E

Snellman, Hanna - H1

Snellman, Hanna (ed.) - H1

Sointu, Liina - M

Sosiaali- ja terveysministeriö - $\mathrm{M}$

Spadea, O. - E

Spadea, T. - E

Stafford, M. - E, L

STAKES - S

Suodenjoki, Sami - I

Sutela, Hanna - K

Söderling, Ismo - D, H1, M

Söderling, Ismo (ed.) - P

Tacke, Ulrich - E

Takala, Pentti - M

Talala, Kirsi - L

Tammisto, Soile - K

Tanner, Arno - H1, M

Tanni, Katri - H1, M

Taskinen, Sirpa - M

Tekkel, Mare - L

Thomson, Elizabeth - F

Tiilikainen, Marja $-\mathrm{G}$

Tilastokeskus - S

Toivanen, Riikka - F

Toivonen, Petteri $-\mathrm{H} 1$

Tolonen, Hanna - L

Torppa, Jorma - E

Tulppala, Maija - F
Tuomilehto, Jaakko - E

Tuominen, Eila - M

Turtiainen, Kati (ed.) - M

Turunen, Teemu - M

Työministeriö - M, Q

Törmäkangas, Timo M. - E

Uhari, Matti - E

Uusitalo, Hannu - D

Uutela, Antti - E

Vaarama, Marja - P

Vaattovaara, Mari - H2

Wahlbeck, Östen - K

Vahtera, J. - E, L

Valkonen, T. - D, E

Valtioneuvosto - M

Valtioneuvoston kanslia - M

Valtonen, Kathleen - H1

Van Lenthe, F. - E

Wardle, J. - L

Waris, Elina - I

Warpula, Kirsi - I

Vartiainen, Erkki - E, F

Wedin, Maud - I

Vendelin, Ismo - H1

Westerlund, Lars (ed.) - I

Westin, Charles (ed.) - H1

Viertola, Cavallari, Ritva-G, P

Viikari, S.A. - L

Vikat, Andres - F

Wildman, Katherine - E

Vilska, Sirpa - F

Winter, Torsten $-\mathrm{L}$

Virjo, Irma - F

Virkamäki, Suvi - H1

Virtala, Aira - F

Virtanen, Arto - I

Virtanen, Marianna - E, L

Virtanen, Pekka - E, L

Virtanen, Petri - K

Volk, Raija - B, H2, J, K

Vuori, Pekka - D

Vuori, Pekka - D, J

Vuorinen, Heikki S. - I

Väestöliitto - M

Väestörekisterikeskus - S

Vähätalo, Kari - K

Väänänen, Ari - E

Xaviera, Torres Joerges - I

Yesilova, Katja - M

Yousfi, Saara - H2

March 7, 2008 